\title{
Sosyal Medyada Roman Etnisitesinin Öz-Temsili ve Ötekilliğin Sosyo-Dijital Telafisi
}

\section{Self-Representation of the Romany Ethnicity in Social Media and Socio-Digital Compensation of the Otherness}

\author{
Semra GÜZEL KORVER ${ }^{1 \oplus}$, Savaş KESKİN ${ }^{2 \oplus}$
}

1PhD Candidate, İstanbul University, Institute of Social Sciences, Department of Radio Television and Cinema, İstanbul, Turkey ${ }^{2} \mathrm{PhD}$ Candidate, İstanbul University, Institute of Social Sciences, Department of Radio Television and Cinema, İstanbul, Turkey

ORCID: S.G.K. 0000-0003-3082-7466; S.K. 0000-0003-0335-9062

Sorumlu yazar/Corresponding author: Savaş Keskin,

Bayburt Üniversitesi Rektörlüğü, Basın ve Halkla İlişkiler Birimi, Bayburt, Türkiye

E-posta/E-mail: savaskeskin@bayburt.edu.tr

Geliş tarihi/Received: 10.09.2019 Revizyon talebi/Revision Requested: 09.10.2019

Son revizyon teslimi/Last revision received: 26.11 .2019

Kabul tarihi/Accepted: 16.12.2019

Atıf/Citation: Guzel-Korver, S., \& Keskin, S. (2019). Sosyal medyada Roman etnisitesinin öz-temsili ve ötekiliğin sosyo-dijital telafisi. Connectist: Istanbul University Journal of Communication Sciences, 57, 51-84 https://doi.org/10.26650/CONNECTIST2019-0088 öz

Bu çalışma, Türkiye'de azınlık oluşları nedeniyle temsil ve tanınma sorununa maruz kalan Romanların sosyal medyayı öz-temsil ve sosyo-dijital telafi platformu olarak kullanışlarının kültürel analitiğini içermektedir. Roman Araştırma Merkezi adıyla Facebook'ta örgütlenen bir grup Roman kullanıcının kimlik inşasını inceleyen çalışmanın amacı, Roman etnik kimliğinin öz-temsil pratiğinin sosyo-dijital koşullar içerisindeki işleyişini, manevralarını ve kültürel görünümlerini saptamak ve dijital inşa eylemlerinin kimlik ve ötekilik arasındaki ilişkiyi dönüştürme biçimlerini Romanlar özelinde anlamaktır. Etnisite ve kültürel kimlik temsiline odaklanan çalışmada, sayfadaki kültürel arayüzleri ve paylaşımları analiz etmek için sosyal ağ etnografisi olarak tanımlanan netnografi yöntemi kullanılmıştır. Yöntem çerçevesinde topluluk sayfasındaki paylaşımlar birer kültürel katman ve kimlik üreteci olarak kodlanmış, geniş çaplı bir gözlem ve doküman incelemesi süreci yönetilmiştir. Betimsel perspektiften yorumlanan kültürel kodlar, Roman kimliğini paylaşan üyelerin 'Biz' olma algısını Türk ulus kimliği ile birlikte düşündüğünü ve 'Gaco' (Roman Olmayanlar) olarak adlandırdığı bir ötekinin varlığını inşa ettiğini göstermektedir. Çalışma bulguları, Roman etnik kimliğinin sosyo-dijital inşa sürecinde özerk ve pozitif kurgular yerine bir savunu, aklanma ve suçsuzluğu ispat etme kurgusunun/kompozisyonunun baskın olduğuna işaret etmektedir. Topluluk üyeleri medyanın görmezden geldiği olumsal kimliklerini göstererek, bir anlamda farkındalık/tanınma boşluğunu kapatmaya çabalamakta ve kendi sorunlarının jeneriğini yaratmayı sürdürmektedir.

Anahtar Kelimeler: Roman, etnisite, kimlik, sosyal medya, öz-temsil

\section{ABSTRACT}

This study consists of a cultural analysis of social media usage as a platform for self-representation and socio-digital compensation of Roman users who are exposed to problems in terms of representation and recognition due to their 
position as a minority group in Turkey. The aim of the study, which examines the identity building of a group of Romany users organized on Facebook under the name of Romany Research Center, is to determine the functions, maneuvers and cultural aspects of the self-representation practices of the Romany ethnic identity under socio-digital conditions and to understand the ways in which digital building actions transform the relationship between identity and otherness in the context of Romany users. In the study, which focuses on representation of ethnicity and cultural identity, the netnography method, defined as social network ethnography, was used to analyze the cultural interfaces and shares on the page. Within the framework of the method, the shares on the community page were coded as cultural layers and identity generators, and a wide-ranging observation and document review process was undertaken. The cultural codes interpreted from a descriptive perspective show that the members who share the Romany identity think about the perception of being 'We' together with the Turkish national identity and construct another identity known as Gaco (Non-Romany). The findings of the study reveal that the organization/ composition of proving laundering and innocence is dominant instead of autonomous and positive constructs in the socio-digital construction process of the Romany ethnic identity. In this case, it may be argued that the community members continue to create an awareness of their problems by closing the information gap in a sense by freely displaying their positive identities that the media ignores.

Keywords: Romany, ethnicity, identity, social media, self-representation

\section{EXTENDED ABSTRACT}

While being a Romany is depicted as 'cute,' 'fun', 'colorful' and 'dynamic' in traditional media, these positive codes that are submitted are associated intentionally with 'absence', 'crime,', poverty', 'lack of education,' 'lower class' and codes related to deprivation. This tendency in the media exposes the problematic sides of recognition. The Romany identity, stamped with many names such as gypsy, lemon borer, snake-eater (Berger, \& Mohr, 2011, p. 107), is forced to adequately cover the parameters of non-culturality, anomaly, marginality and non-communality prevailing in urban markets as a form of congestion in the ghetto or suburbs outside the city walls (Wacquant, 2011, p. 11). So, the cute object of representation is the idea that an 'Other' separated from 'Us' is a meaningful construct within the boundaries of existence. As a matter of fact, when we look at studies focusing on Romany views, images and other types of representations in the traditional media (Illhan, \& Firat, 2017; Posos-Devrani, 2017; Akgül, 2006; Dişli, 2016; Alp, 2016), there is consensus that this category of ethnic and collective identity is constructed between the slightest valorization of negation and the parameters of various levels leading to defamation and hate speech. Moreover, the representation power of the Romany identity is largely used by 'Non-Romany' perpetrators. This form of representation is the mediatic reflection of the 'passive recognition' that gets the Romany identity stuck within certain stereotypical criteria based on the dominant/ distinguished sense of identity in Turkey. 
This study aims to understand how Romany users, who are a significant vulnerable group in Turkey, phrase the negative/problematic and positive codes that they think are associated with their identity on social media and to read their practices of constructing ties and distances with the Other/Non-Romany through digital cultural outputs. For this purpose, we examined the compensation mechanisms, alternative socialization and self-representation practices designed by a group of Romany citizens organized under the name of Romany Research Center on Facebook, for some damages in their identities which have been reduced to the problem of misrepresentation in media and social networks. In contrast to the traditional media's passivity outlined above, the possibilities of self-representation that social media offers to its users mediate privileged media and community schemes in which many disadvantaged identities can share themselves freely (Özmen, \& Keskin, 2018, pp. 535-536). This study was modelled as a digital culture study with a netnography approach, where it is assumed that there are several differences in identity constructions between self-representation actions in social media and traditional representations. This is because this action is characterized by the fact that the Romany are active/acting subjects who talk about themselves and others, and are not passive, spoken about objects. The self-representation here also includes a digital adaptation of the 'self-determination' concept, which is often mentioned in relation to the issue of minorities. As a result, a small-scale fundamental act of a people trying to determine its own destiny in representation is present. This argument is also important in terms of contributing to a new debate in which ethnocentric reducers are criticized.

The distinction between ' $U s$ ' and 'the Other' is seen in the majority of the shares on the community page. In the discourses where'the Other' is hidden, an anonymous feast that excludes, despises and insults the Romany is clear, but in clear speeches, it is acceptable to call 'the Other' by name: 'Gaco'. Gacos, i.e. non-Romany, are defined and represented as those who often humiliate the Romany in the identity-based activities of the community, are unaware of Romany culture, use the Romany for their own interests when appropriate, use hate speech when talking about Romans in their daily lives or in special situations, and use a marginalizing language. As a result, identity construction in the Romany Research Center should be considered as a collective compensation and restoration activity rather than a 'positive' and 'constitutive' action. This is because the concept and the main idea of what is going on in this community has traces of an unrecognized justification effort. Although it is a Romany platform, a digital purification chain and evidence of innocence are aimed to be constructed against the accusations 
directed by society. What the Romany do in this community is to say that they are not as accused by others as much as they describe themselves. Romany users who get the chance to talk about themselves on social media show a reflex of socio-psychology of defense, which essentially does not allow them to express themselves. In the framework of the cultural production in the community, it may be argued that the Romany have transformed their own identity codes that are belittled by society into a counterrepresentation, and they have aimed to establish the Romany counter-image by expressing their problems in ways not available in the traditional media. 


\section{GíRiş}

Roman temsiliyetini 'edilgen' bir aktivite olmanın çok daha ötesinde, tarihsel birikimleri ve geleneksel kimlik ilişkilerini başkalaştıracak yetkinlikteki 'öz-uğraşı' ya da 'kendi için uğraşı' temelinde değerlendiren bu çalışma, egemen kimlik yaratılarına alternatif/muhalif olarak kendi hesabına çalışan bir 'öteki' kimlik inşaatını ya da en azından restorasyonunu incelemeye almaktadır. Roman olma halinin gündelik konvansiyonel tezahürlerinin işaret ettiğinden aksi yöne odaklanan bu çalışmada, Romanların kendi sosyal medyatik ekranlarında pratiğe aktardıkları telafi ve öz-anlamlama çalışmalarının seyrüseferi okunmaktadır. Bir 'öteki' kimlik standardındaki Roman etnisitesi ile egemen kimlik arasındaki ilişkide, geleneksel temsilin dışında olup biten bu'yeni' oluşlar ve oluşturmalar silsilesi, 'tanınma' merkezli kimlik siyasetine de göndermeler yapılarak ele alınmaktadır. Çünkü McLuhan (1962), Baudrillard (2015), Žižek (2019) ya da Baker'in (2017) hatırlattığı üzere, ekranlarla etkileşim halinde ve'ekrana dönük'bilinçle örgütlenen anlamlara maruz kalmak ya da onları arzulamak, kayıtsız/aldırışsız kalmayı imkansız hale getirir ve geleneksel olanın dönüşümünü mutlak güzergah olarak henüz yüzleşilmemiş bir gerilimle başlatır. Medya nesnelerinin deneyimsel dünyada nasıl yeniden yaratıldığını, konumlandırıldığını, kullanıldığını ve bunların kendimizi, kimliklerimizi ve diğerlerini/ötekileri yaratmaya nasıl yardımcı olduğunu bir grup Roman kimlikli çevrimiçi kullanıcının öz-temsil pratiği özelinde anlamaya çalışma eforu, dönüşme ihtimali taşıyan kimlik edinçlerine ve teamüllerine bir yerinden katkı sunma amacıyla eşgüdümlüdür.

Roman gruplar, Türkiye'nin belli coğrafi bölgelerindeki parya halleriyle kümelenen, 'pek de' rahatsız edici görünmeyen ancak olumlanan bir kimliğin değerlerini de tam olarak karşılamayan bir sosyal tanınma arz eder. İletişim kurmak zorunluluğu bulunan, görülen, dinlenilen ancak tam olarak yeri saptanamayan, yakınlığı ve uzaklığı kestirilemeyen, 'Biz'in parçası olup olmadığı hakkında kesin konuşmalara izin vermeyen bu tarzdaki öteki kimlikler, onlarla ne yapılacağı konusunda bilinmezlik, şaşkınlık ve izafi kaygılar nedeniyle dışlama ve uzaklaştırmaya maruz bırakılabilir (Bauman, 2009, pp. 65-66). Roman olma hali, geleneksel medyadaki'sevimli,'eğlenceli,',renkli' ve'dinamik' olarak gösterilirken, bu olumlanan kodların bilinçli bir'yokluk,'suç','fakirlik','eğitimsizlik', 'alt sınıf' ve mahrumiyet kodları ile ilişkili sunulması tanınmanın sorunlu taraflarını açık eder. Çingene, limon sıkıcısı, yılan yiyen gibi (Berger, \& Mohr, 2011, p. 107) birçok isimle damgalanan Roman kimliği, kent çeperlerinin dışındaki 'getto' ya da 'banliyölere' sıkışık bir inşa biçimi olarak, kent paryalarında hüküm süren kültürsüzlük, anomali, marjinallik ve toplum dışılık parametrelerini (Wacquant, 2011, p. 11) yeteri ölçüde kapsamaya 
zorlanır. Bu nedenle temsilin sevimli nesnesinin aslında, 'Biz'den ayrılan bir Öteki'nin varlık sınırları içerisinde anlamlı bir yapı olduğu fikri gün yüzüne çıkar. Nitekim geleneksel medyadaki Roman görünümlerine, imajlarına ve diğer tipteki temsillere odaklanan çalışmalara bakıldığında (illhan, \& Fırat, 2017; Posos-Devrani, 2017; Akgül, 2006; Dişli, 2016; Alp, 2016), bu etnik ve kolektif kimlik kategorisinin olumsuzlamanın en hafif değerlikleri ile tahkire ve nefret söylemine varan çeşitli kademelerin parametreleri arasında inşa edildiğine dair oydaşma görülmektedir. Üstelik Roman kimliğinin temsil gücü çok büyük oranda 'Roman Olmayan' failler tarafından kullanılmaktadır. Bu temsil biçimi, Roman kimliğini Türkiye'deki egemen/seçkin kimlik algısı cenderesinde zaman zaman içe kıvıran ve belirli stereotip kıstaslarda sabit tutan'edilgen tanınma' pratiğinin medyatik yansımasını ifade etmektedir. Öyle ki Levinas'a göre (1998, p. 9) öteki kimlik başkaları tarafından tanımlandığında ve temsil edildiğinde, özgün 'başkalığını've farklı olma halini yitirerek 'Biz' idealinin sentetik bir parçası olur.

Yukarıdaki kuramsal problem özetlemesi çerçevesinde bu çalışma, kimliğin farklılık üreten ve farklılıklarla üretilen bir ilişki biçimi olarak (Connolly, 1995) Romanların 'tanınma' faaliyetlerindeki inşa biçimlerine odaklanmaktadı. Sosyal medyada yeniden kodlanan ve Roman olduğu varsayılan kullanıcıların bilfiil katkılarıyla kültürel jenerikleri kurgulanan Roman kimliğinin, bir sosyo-dijital telafi etkinliği çerçevesinde olumsallık kazanmasının çeşitli uygulamalarını irdeleyen bu çalışmada, Türkiye'deki kimlik konulu müstakil litaratüre özgün bir fayda sağlamayı hedeflenmektedir. Çalışmanın temel amacı, Roman kimliğinin sosyal medyadaki topluluk örgütlenmelerinde üretilen öztemsil pratiği ile yeniden inşa edilme biçimlerini ve sosyo-dijital telafi faaliyetlerinin onarmaya çalıştığı kodları mevcut kültürel üretimler çerçevesinde haritalamaktır. Bu amaçla Facebook'ta 'Roman Araştırma Merkezi' adıyla örgütlenen bir grup Romanın, medya temsilleri ve toplumsal ilişki ağları içinde'yanlış tanınma' sorunsalına demirlenen kimliklerindeki bazı hasarlar için tasarladıkları telafi mekanizmaları, alternatif toplumsallaşma ve öz temsil pratiklerine bakılmıştır. Çünkü sosyal medya toplumsallığı bu çalışma içerisinde, geleneksel medyanın temsil yaklaşımından farklı olarak dezavantajı kimlik gruplarının yararına işleyebilen öz-temsil düzenekleri barındırması nedeniyle farklı bir bağlamda ele alınmaktadır. Nitekim bu konuya eğilen çalışmalarda saptanan duruma göre, sanal topluluklar birçok dezavantajlı kimlik müntesibinin kendilerini özgürce paylaşabilecekleri ayrıcalıklı medya ve topluluk tasarılarına aracılık etmektedir (Özmen, \& Keskin, 2018, pp. 535-536). Bu tespiti bir varsayım olarak kabul eden bu çalışmada, Roman kimliğini merkez kabul eden Türkiye menşeili sanal topluluk kamuları arasında, üye sayısı, paylaşım ve etkileşim sıklığı, kamusal müzakere konularındaki 
çeşitlilik, kimliği ele alma biçimleri, kolektif dayanışma ritüelleri, demografik temsil ve formel oluşumlarla ilişkiler gibi kriterler bakımından öne çıkan Roman Araştırma Merkezi, araştırma sahası olarak seçilmiştir.

Netnografi yaklaşımıyla bir dijital kültür araştırması olarak modellenen bu çalışmada, Roman Araştırma Merkezi'nin kimlik konulu tüm aktiviteleri, bir kültürün ve dolayısıyla da kültürel ve etnik kimliğin inşacı eylemleri olarak düşünülmektedir. Çünkü etnografik perspektifle anlaşılmaya çalışılan bu sosyo-dijital aksiyonun karakteristiği, Romanların hakkında konuşulan edilgenler değil, kendileri ve başkaları hakkında konuşan aktif/ eyleyici özne olmalarıyla biçimlenir. Buradaki öz temsil, azınlıklar meselesinde sıklıkla zikredilen 'öz belirlenim/self-determinasyon' kavramılla da ilintili dijital bir uyarlamayı içine almaktadır. Neticede, temsil konusunda kendi mukadderatını belirlemeye çabalayan bir kitlenin küçük çaplı da olsa kurucu atağı mevzubahistir. Bu bağlamda, Roman Araştırma Merkezi topluluk sayfasındaki tüm sosyo-dijital paylaşımlar (sözeylemler, görsel tasarımlar, fotoğraflar, videolar, yorumlar), Roman etnik kimliğini yeniden inşa eden ve onaran kültürel kodlar olarak yorumlanmış; Kozinets'in (2010) geliştirdiği netnografi yaklaşımının esaslarına ve aşamalarına göre tasnif edilerek bir sanal topluluk anatomisi ile kültürel kimlik arasında işlevsel bağıntılar kurmak için çözümlenmiştir.

\section{Türkiye'de Roman Kimliği: Durum Tanımı ve Örgütlenmeler}

Dünyanın hemen hemen her yerinde yaşayan Romanlar/Çingeneler, yaşadıkları yerler birbirlerinden ne kadar farklı olursa olsun, kendilerine verilen adların yüklü olduğu tahkirli anlamlar ile tanımlanma ve damgalanma potansiyeli taşımaktadır. Kimlikler arası eşitsizliği ve denksizliği niteleyen bir sıfatlar dili olan damgalar, kurumlanmak isteyen egemen/seçkin kimliklerin 'öteki' olan üzerindeki söylemsel ve sembolik hakimiyetini kurar. Goffman'a göre (2014, p. 183), damgalar öyle şeylerdir ki, bir sıfat olmanın ötesinde yaşayan ilişkilere dönüşürler. Canlılıkları ya da ölülükleri, içeriden ya da dışarıdan olmaları, sağlık ya da hastalık göstergeleri tam bir muammadır. Yalnızca bir kimlik kategorisinin diğerinden farklı olduğu gerçekliği, farkın eşitsizliğe dönüştürülecek bir dilsel tahakküm ile kontrol altına alınmasıyla birlikte damgalama (stigmatization) stratejisi çalışır. Romanlar bu nedenle bulundukları ülkelerde çağrılmak istedikleri adlardan daha çok toplumsal damgalarıyla çağrılırlar.

Romanlara yönelik olarak kullanılan dışlayıcı, ötekileştirici ve ayrıştırıcı ifade kalıplarının (üvey evlatlar, vatansızlar, paryalar, yersiz-yurtsuzlar) uyandırdığı rahatsızlık 
hissi, 1978 yılında organize edilen Dünya Çingeneler Konferansı'nda somut bir adıma katalizör olmuştur. Bir tür damgaya dönülen Çingene kelimesi yerine 'adam, insan' anlamlarını taşıyan'Rom'kökünden gelen'Roma' (Türkçesi Roman) ifadesinin kullanılması deklare edilmiştir (Yanıkdağ, 2012, p. 248). Kendilerini tanımlama gayreti her ne kadar bir tanınma politikasını çağırsa da çok az kimlik türü bu ayrıcalığa sahiptir ve öteki olanın kimliği genel olarak ondan bağımsız ya da en azından özerk konumda form üretir. Bu nedenle Romanların damgalarla çağrılması sorunu bugün de gerilim yaratan, süreğen ve kemikleşmiş bir sorundur. Romanların yüz yüze oldukları damgalanma biçimi ise Goffman'ın sözünü ettiği $(2014$, p. 33) üç tip damga kategorisi içerisinde'ırk ve etnisite' tabanlı olan en yaygın türe dahildir. Roman olma hali her şeyden önce, etnik bir örgütlenme ve kimliklenme hali ile hemzemin hareket alanında manevra yapmak zorundadır.

Etnik kimliklerin temelinde etnisite tanımları ve mensubiyet bulunmaktadır. Yunanca 'ethos' sözcüğünden türeyen etnisite kavramı, genellikle ortak bir köken, doğum yeri, kabile, kavimler gibi beşeri birlik durumuna atıfta bulunmak amacıyla kullanılmaktadır (as cited in Nişancı, \& Işık, 2015, p. 198). Yalçıner'e göre (2014, pp. 191-192), nispeten yeni bir kavram olan etnisite genel hatlarıyla etnik grup temelli bir aidiyet biçimi, etnik kimliğin kurucu özü veya bir gurubun diğerlerinden ayırt edilebilmesine olanak sağlayan kıstaslar olarak değerlendirilmekte ve iki farkıı bakış açısıyla ele alınmaktadır. Birinci yaklaşım olan ilkçi bakış açısı, etnisitenin verili, doğal ve süregiden özelliklerini ön plana çıkarırken, ikinci yaklaşım olan araçsalcı bakış açısı ise, onun tesis edilen fonksiyonel bağlamı ile ilgilenmektedir.

Bireylerin dünyayı tecrübe etme serüvenleri, onların bir kökenle örtüşen kültürel paydaşlıklarda buluşmalarını zorunlu kılmaktadır. Bu nedenle etnik kimlik genellikle soy, ortak bir dil, köken ve bazen de dinle alakalıdır. Onun dinamik, karmaşık ve çoğu zaman akışkan yapısı nedeniyle, atfedilen ve kabullenilen kimlikler arasında bir uyumun yanı sıra bir çatışma da söz konusu olabilmektedir (Akıncı, 2014, p. 34). Çünkü her birey ya da grup kendine ilişkin etnik tanımlamalarla birlikte, başkalarının ona ilişkin etnik yakıştırmalarına maruz kalmaktadır. Yakıştırmalar, ötekilik kapsamındaki aşağı görme halini kapsadığı ölçüde, etnik kimlikler arasında bir çatışmanın yaşanmasına neden olmaktadır.

Etnisite ile yakın ilişkideki yerlilik ve yerelliği kesin bir çizgi ile ayırmak ve birbirlerinden dışlamak gerektiğini savunan Aytaç (2017), yerelliğin bir yerin diğer yerler karşısındaki 
evrensel özgünlüğünü tarif ettiğini, yerlilik söz konusu olduğunda ise topluluk güçlerinin bir yabancının ya da düşman imgenin varlığına yönlendirilmesi ihtiyacının ortaya çıktığını yazar. Bu bakımdan Roman olmanın olanaksız yerelliği yani yersiz-yurtsuzluğu, etnik ve kültürel özgünlüğe set çeker. Yerlilik ve bir çatı kimlik olarak ulusallık söz konusu hale geldiğinde ülke sınırları içerisinde güçlü bir birleşme ve dayanışmadan söz edilmelidir. Çünkü Romanlar milli kimliğe katkı yapan kodları yeterince içerir, ancak onların etnik ve kültürel kimliklerinin kodları, milli kimlikten bağımsız olarak kurulur. Türkiye'deki Romanlar, yerlilik fikrine sadakatle uyum gösteren ancak etnik kimliğine sadakati de önemseyen iki uçlu bir tanınma stratejisi izlemektedir.

Roman kimliğinin Türkiye'deki varlığı, azınlık bir grubun öteki olma 'haleti ruhiye'si üzerinden sürdürülen bir tanınma politikasına bağlı olarak biçimlenir. Nitekim Taylor'a göre (2005, p. 51) modern çağda kimlik sorunları genel hatlarılla politik, hukuki ve sosyal tanınma potalarına indirgenir. Bu nedenle kimliğin kapsamlı bir tanınmaya konu olması ya da olamaması arasında yıpranan bazı kodlar için onarımsal eylem kolektifleri çalışır. Türkiye'de 'de facto /fiili' olarak azınlık sıfatı taşıyan ancak 'de jure/hukuki' olarak bir tanınmaya erişemeyen Romanlar, Osmanlı İmparatorluğundan beri süregelen'gayrı müslim' odaklı azınlık tanınmasının (Oran, 2010, p. 12) dışında kalmaktadır. Birleşmiş Milletler çalışmalarında azınlık kaideleri her ne kadar 'etnik, dilsel, dinsel ve kültürel' kategorilerini (Oran, 2014, pp. 25-26) içerecek biçimde hazırlansa da Türkiye'de azınlıklar meselesinin henüz etnik kapsamda geçerlik kazanmadığı bir gerçektir. Bu nedenle Roman kimliği Türkiye'de tanınma ile tanınmama ya da en azından kısmen tanınma (Taylor, 2005, p. 42) aksındaki akışkan rotada kurulur.

Bir azınlık grubu olarak Romanların Türkiye'deki nüfus demografik varlıklarını inceleyen araştırmalardan derlenen panoramaya göre, 2 ile 5 milyon arasında değişen bir popülasyondan söz edilebilir (Karan, 2917, p. 6). Bu değişken aralık, kimliği ifade edememe, suskunluk ve kayıt dışı nüfus hareketleri gibi nedenlere bağlı olma potansiyeli taşımaktadır. Tamamına yakını yerleşik yaşam süren Romanlar, iskan ettikleri bölgelere Roman, Çingene ve Abdal gibi isimlerle çağrılırken farklı coğrafi bölgelere yayılan ve bulundukları lokal kültürle özdeşleşen üç ana gruba ayrılır: Domlar-Güneydoğu Anadolu Bölgesi, Lomlar-Kuzeydoğu Anadolu Bölgesi ve Romlar- Batı Anadolu Bölgesi (Kolukırık, 2008). Romanların bölgesel yayılımı, diğer etnik gruplarla yakınlaşmaları ve kültürel paylaşımda bulunmalarına neden olarak dinsel ve dilsel farklılaşmaları beraberinde getirmektedir. Bölgesel dağılımların oluşturduğu yöresel farklılıklara bağlı olarak Romanca, Domca, Lomca veya Teberce konuşan Romanlar, yine coğrafik yerleşimlerine 
göre Türkçe ve Kürtçeyi de iyi derecede konuşabilirler (Karan, 2017, p. 6). Bunun yanı sıra inanç orijininde bakıldığında Türkiye'deki Romanların önemli bir bölümü Müslümandır ve Sünni mezhebindendir. Abdallar ise Müslüman olmakla birlikte Alevi/Bektaşi doktrinlerine göre yaşamlarını sürdürürler. Az sayıda da olsa Hıristiyanlığın çeşitli mezheplerinden Romanın etnik varlıklarını korudukları görülür (Marsh, 2008, p. 26).

\section{Sanal Topluluklar ve Kimliğin Sosyo-Dijital İnşası}

Toplumun genelinde görülen eğilime paralel olarak Romanlar, gelişen ve değişen iletişim teknolojileri doğrultusunda sosyal medyada da örgütlenirler. Çünkü sosyal medya bireylere topluluk hislerinin paylaşılacağı dayanışma ve değiş tokuş ağlarının merkezinde olma, süreçleri idare etme, çevreyi dilediği gibi biçimlendirme ve kimliği yeniden tasarlama gücünü (Donath, 1998, p. 1) sınama, kullanma ve geliştirme imkânı verir. Sosyal medyayı modelleyen kod yapısının esnekliği, bireyin fantezileri ile en hakiki yaratılarını aynı tabanda buluşturur ve özdüşünümselliğinin müdahaleye açık yanlarını dijital alanlarda akıcı bir biçimde ifade etmesini telkin eder. Sosyal medyada Roman olarak örgütlenmenin, bir topluluk oluşturmanın, geleneksel bağlamdaki kodlardan bağımsızığı nedeniyle bir takım farklılıklar içermesi beklenebilir. Çünkü sosyal medya, var olanın sınırlıklarını görece kullanıcıların ortak kontrolüne sunarak merkezi kurumların baskın deterministik etkilerini sönümlendirir ve kimlik sorunsallarını kendi lehlerine yeniden kurgulayabilmelerinin önünü açar. Bu çalışma sistematiğindeki temel ilgi, Roman kimlik paydaşlarının sosyal medya toplumsalıklarını gerçeklikle nasıl bir ilişki içerisinde inşa ettiğini hesaba katar. Sosyal medya temsiliyeti, gerçekliği yıkmak ya da tekrar etmek arasındaki bir yelpazedeki sonsuz tekrarla hesaplanabileceği için, Roman kimliğinin hangi kademede konumlandığının açıklanması önem taşır.

Sanal topluluk örgütlenmeleri, bireylerin kendilerine yeni konfor ve kolektif üretim olanakları tasarladıkları yapılanma biçimlerini tarif etmekte yardımcı olurken, Roman kimliği gibi dezavantajlı oldukları saptanabilen (Dişli, 2016; Uzpeder et al., 2008) kimliklerle sosyalleşen bireylerin çok yönlü telafi ve olumlama stratejilerini organize ettikleri uzamlar olarak da değerlendirilebilir. Bu kapsamda sanal topluluk ve kimlik ilişkisini irdeleyen teorik yaklaşımları, Roman kimliğini çağrıştıracak biçimiyle yeniden okumak gerekir.

Yeni medyanın katılımcı kültürü konusunda ayrışmalara neden olan sanal topluluk ekranı, milyonlarca çevrimiçi kullanıcıyı ortak kültürel ara yüzlerde toplayarak, 
kanaatlerinin ve gündelik yaşam hakikatlerinin yeniden yorumlanmasını mümkün kılar. Jones (1997, p. 3), sanal toplulukların en az iki etkileşimci, etkileşimin yaşandığı kamusal alan ve paylaşımın sürekli olduğu sosyal oluşumlar içerdiğini belirtir Sanal topluluk kavramı, geleneksel kurulumlarda olduğu gibi organik bir yapı ve çok sayıda katılımcı gerektirmez.

Bireylerin ilgileri çerçevesinde yeni medyayı bir kamusal müzakere alanına dönüştürmeleri sonucunda kurulan sosyal oluşumlar, esnek ve dijital bir tasarıma sahiptir. Bu tasarımlarda, bireyin topluluk biçimlerini ve topluluk içindeki varlığını denetlemesi, yoklaması ve yenilemesi oldukça muhtemeldir. Geleneksel olan ile kıyaslandığında değişimin görece daha az gerilimle gerçekleştiği sanal topluluklarda, bireylerin düşük aidiyetlerinin bir uzvu olarak kamusal bağların daha zor geliştiği görülür (Donath, 1998, pp. 3-4). Bireyleri bir arada tutan ilgiler ortaklığı, ilginin cazip seçeneklerinin sürekli üretilmesini bir ödeve dönüştürebilir. Ancak bu ortamlardaki etkileşimin ya da empatik yerleşimciliğin bireylerin hakikat algılarının şekillenmesinde doğrudan tesiri saptanabilir.

Sanal topluluklardaki etkileşimin niteliği üzerine geliştirilen görüşler, dijital tabanlı ve sentetik temaslarda mutabık kalı. Wellman ve diğerleri (1996, pp. 217-218), bilgisayar destekli sosyal ağlar olarak tasvir ettikleri sanal toplulukların, temelde bilgisayar aracılı bir iletişim sistemiyle hacim kazandığını ve buralarda temsili bir etkileşim yaşandığını vaaz ederler. Sanal toplulukların ekranlarda görülen ve yalnızca buralara özgü olan gerçekliği, bir aracın yetkesini de sürekli canlı tutar. Ekranların hikmetini sorgularken, kendilerini ekranda yansıyan görünüşleri/imajları üzerinden tanıyan ve nispeten kurabilme yetisi taşıyan bölünmüş kitlelerin 'her şeyi' içine alan ve dijital kodlarca içerilen varlıklarının bir sanal bir temsil olma serencamlarını hatırlamak gerekir. Çünkü asıl gerçekliği etkileyen sanal topluluklar, bedenlerin olmadığı bir ekrandaki sözeylemler aracılığıyla hislerini, bilgilerini ve ilişkilerini paylaşan bireylerin, mekandan ve zamandan özerk birliktelikler kurdukları elektronik bir etkileşime dayalıdır (Rheingold, 1994, p. 58).

Donath'a göre (1998, pp. 1-2), sanal topluluklar katılımcılarını kimliklendirir. Sanal toplulukların üyelerine isnat ettiği kimlikler, dijital yerleşimcilikten bağımsız düşünülemez. Kodlanan geleneksel kimliklerin sanal kodları içerimlediği melez bir türün varlığından söz edilebilir. Sanal topluluklarda kimlikler, hem kolektif bir yapıya karakter yüklemesi hem de bireylerin mensubiyetlerini anlamlandırması bakımından önemlidir. Bu nedenle sanal topluluklar geleneksel çağrımları, takma isimleri, ideal sözceleri ya da damgalamaya 
yönelik sıfatları seçerek, kendine tanım oluşturmaktadır. Topluluğun varlığının somut delili ve görüntüsü olan bu isimler, kişilerin kimlik yapılarına da sirayet etmektedir.

Wellman ve Gulia (1999, pp. 1-2), sanal toplulukların; umut, aldatma ve gerçeklik gibi üç farklı uç arasında etkileşim kurduğunu söyler. Bireyleri bir araya getiren postmodern bunalımlar, gerçekliğin kimlik düzeyinde telafine yönelik bir umudun inşasında rol oynar. Kullanıcılar, maruz kaldıkları ve değiştiremedikleri geleneksel kimlik değerlikleri üzerindeki kolektif oynamalarla bir umudu müşterek kültürde toplayabilir. Umudun canlılığı bireylerin zihinsel süreçlerini kontrol ederek, gerçeklik içinde ziyaret edilen belli belirsiz bir vahayı tasarlar. Bu vaha, bir kaçış noktası ve zaman zaman da kurgusal aldatmacadır. Çünkü umut ve kanaatler yoluyla asıl gerçekliği ikame eden kimlik umutları üretmek, çevrimdışı yaşamdaki toplumsal hareketliliğin krizlerini de beraberinde getirebilir. Sanal topluluk gerçekliği ile organik gerçeklik arasındaki fark büyümeye başladığında, kimliğe dair umudun aldatıcı yanları daha belirgin hale gelir. Böylece bireylerin içinde bulundukları organizmayla uyumsuzluk geliştirmeleri ve sanal topluluk aidiyetlerini pekiştirmeleri gibi tansiyonlu bir süreç yaşanması beklenir.

\section{Egemen Temsile Karşı Öz-Temsil}

Kültürel kimliklerin ve etnisite temsilinin kod sistemini deşifre etmek ve dilin anlamsal yapı hareketlerinin durum tanımlarına dönüşüm yollarını açımlamak isteyen Hall'in 'Temsil Teorisi' göre (2017), bir şeyin aslının yerini tutacak kadar etkin bir mekanizmayı zinde tutan temsil hareketlerinde mutlak ve asgari iki taraf vardır. Temsil ise bu iki taraf arasındaki ilişkiyi kurmak ve denetlemekle görevlendirilen davranışlar bütününü kapsar. Hall'in ifadesiyle (2017, p. 340), ırksal ve ziyadesiyle etnik çağrışımlar özelinde kurulan öteki imgeler, genellikle bir fetişler dünyasının yaratılması ve fantezilerin kol gezdiği klişe tiplerin türetilmesi ile pratikleşir. Medya içeriklerindeki Roman tiplemelerine kimlik isnat edileceği zaman, seçkinlerin fantezi dünyalarının derinliklerinde yatan fetiş kurmacalar da devreye girer.

Hall (2017, pp. 303-307), öteki olanın temsiline ilişkin anlam odaklı geleneksel yaklaşımı farklı bakış açılarından görmeyi dener. Dilbilimci perspektifte sembolik anlamın önemini belirterek, anlamın ancak farka dayalı olduğunu ve 'başkasıyla' diyaloglar yoluyla kurulabildiğini savunur. Ancak bu diyalog çoğu zaman egemenin çok taraflı konuştuğu bir monolog olarak işler ve esasında temsil denilen şeyin kendisi ise 'başkasının yerine davranmak ve onun yerine kendi için konuşmak' olarak tasvir edilebilir. Öteki'nin 
temsiline antropolojik olarak da yaklaşan Hall, kültürel anlamın dağıtımında temsile dayalı bir rekabet olduğunu kabul ederek gücün ağırlık merkezlerinde toplaşan bir anlam seti olduğunu doğrular. Öteki'nin temsilinde psikanalitik güdüleri de arayan Hall, başkası olarak tanımlanan şeyin, 'Ben' olarak tanımlanmak istenen kimliğin inşasında tamamlayıcı bir unsur ve patolojik karşıtlık olduğunu düşünür. Bu görüşlerin kesişim kümesinde ise, öteki olanın temsiliyetine hükmeden ideolojik bilincin 'başka' ya da 'farklı' olanı 'Biz' olandan kesin çizgilerle ayırma ve aradaki farklılıkları gündelik çıkarlara göre sündürerek kötü gösterme/şeytanlaştırma argümanlarını görmek mümkündür.

Sosyal medya söz konusu olduğunda ise temsil ilişkilerinde kökten bir başkalık ve transformasyon hakkında konuşmak gerekir. Çünkü yeni medya altyapısında kurulan sosyal medya ve diğer kültürel arayüzler öncelikle dijital kod sistemine tanımlanmayı, yani temsil edilmeyi gerektirir. Manovich'in (2001, pp. 27-30) sayısal temsil (numeratical representation) olarak kavrama döktüğü bu dijital dolayımlamada, gerçekliği kuran tüm objeler, düşünce sistemleri, kültürel aktiviteler ve nihayetinde insanlar; dijital yazılımlarda birer sayısal kod olarak yeniden yazılır ve bu kodlarda gelenekselin etkileri sönümlenir. Sosyal medyada her şey 'efektif' müdahalelere maruz kalarak dönüşür ve aurası ile arasına birtakım mesafeler koyar. Sentetik, değişken, modüler, esnek, otomasyonel, geçirgen ve çevrimli (Manovich, 2001, pp. 30-50) bu yeni temsil, simülatif bir iletkenliği ve kimlik menşeili sosyo-dijital iletişimsel eylemlerin tarafları arasındaki eşitsizliği de tersine çevirebilir. Žižek'in (2006) bir 'paralaks' olarak gördüğü sapmalar ve kırılmalar, ideolojik bilincin yanlışlığına göz yummayan bazı dezavantajı kimlik eyleyicilerinin kendi dengeleyici taktiklerini sergiledikleri sembolik mücadele alanlarına yeni bir sinerji kazandırır. Nihayetinde Sosyal medya, öz-kimlik temsiliyetinin'sembolik etkileşim setlerini' (Mead, 1934) ve 'simgesel şiddet' varyasyonlarını içeren, 'sosyal sermaye' odaklı bir çatışma ve uzlaşma'alanı' (Bouerdieu, 1989) olarak Roman kimliğinin inşacı ve araçsalcı öz-temsil edimlerine aracılık etmeye uygundur.

Öz-temsil, bir başkası tarafından temsil edilmek yerine, kişinin kendini referans alarak ve bilfiil eylediği bir inşa biçimini gerektirir. Öz-temsilin edebiyat (Seber, 2013), sinema (Penkins, 2000) ve televizyon (Corner, 1995) gibi birçok araçsal kuşağı bulunmasına karşın, sosyal medyanın sunduğu multi-medya olanaklar durumu farklı katmanlara taşır. Sosyal medyada öz-temsil, en temel anlamda Jenkins'in de değindiği gibi, bireylerin monopol medya kartelleri ve info-kapitalistlerin egemenliğindeki temsile karşılık, kullanımlarında olan araçlar üzerinden kendiliklerini anlatması, resmetmesidir. Bu noktada, 'çevrimiçi kendilik' ile 'aracılanmış kendilik' arasında kesin bir çizgi çekmek 
gerekir. Çünkü aracılanmış kendilik açık bir temsile işaret eder. Bireyin ya da grubun kendilerine ilişkin tasarımları dijital sistem aracılığıyla dolaylanır ve özne tarafından icra edilir (Enli \& Thumim, 2012, pp. 89-90). Romanların sosyal medyadaki kopuk ve enformel gezginlikleri çevrimiçi kendilik kategorisine girerken, doğrudan temsile dayalı aktiviteler ise aracılanmış kendilik çerçevesinde kimliğin öz-temsilini içerir.

Sosyal medyada öz-temsil üç aşamada gerçekleşir: evrensel kendiliği bireyselleştirme, öz-temsilleştirme ve baskın temsili oluşturma, kendi hakkındaki temsili kontrol etme (Enli \& Thumim, 2012, p. 98). Modernitenin kolektif meta anlatıları ekseninde bütünleşen bireysellikler, post-modernitede yeniden parçalanır ve öz-temsil açısından en elverişli yöntem, bireyin evrensel varlığı içerisinde kendini rafine ederek öz-bireyselliğini ortaya çıkarmasıdır. Bireyselliğin keşfi sonrasında kendiliğin sunumu gerçekleşir ve baskın anlamlar bu temsil aracılığıyla kurgulanır. Öz-temsil sistematiğinin, blog yazarlığı, selfi ve görsel öz-temsil, niceliksel ve niteliksel öz-temsil (Rettberg, 2017); sunum aktivitesi, poz verme, çok insanlı foto ve çevre yoğunluklu (Musse, 2016) gibi birçok baskın sunum ve denetim türü vardır. Bireyler, yeni medyanın fonksiyonları ve anlatı aparatları sayesinde kendiliklerini sayısal ya da sayısal olmayan özellikler setiyle kurgulayabilir. Roman kimliğinin bu bakımdan, niceliksel ve niteliksel birçok kodu taşıdığı söylenebilir. Yeni medyanın getirdiği en önemli yeniliklerden biri olan öz-temsil bolluğu, tikel medyaların özerk öz-temsil pratiklerini biçimlendirmekte ve katılımlı ekranlardaki denetim çoğu zaman temsil sahibinin kontrolünde gerçekleşmektedir.

Sanal topluluklardaki öz-örgütlenmelerde, kimliklerini bir öz-temsil pratiğine dönüştüren Roman aksiyonlarını, bir anlatı ekseninde de düşünmek gerekir. Çünkü kimlik, her şeyden önce bir anlatı olarak dilsel pratikler ile sembolleşir ve etkileşime dökülür (Hall, 1997). Bu bakımdan son dönemde sıkça zikredilen Dijital Hikaye Anlatıcılığı fikri, Jenkins'in (2006, p. 93) 'transmedya anlatılar' görüşleriyle tutarlı bir biçimde, bireylerin kendi medyalarındaki öz-temsil özgürlüklerinin çerçevesini çizer. Romanların yapmakta olduğu şey, yeni medyanın multi-enstrümanlarını bir araya getirerek kimliklerini anlatıya dönüştürmek ve kitlelerin etkilenmesini beklemektir.

\section{AMAÇ VE YÖNTEM}

Bir kültür araştırması olarak ve nitel veri paradigmasına sadık kalınarak modellenen bu çalışmada, Roman kimliğinin sosyo-dijital kültürel koşullar içerisindeki öz-temsil pratikleriyle biçimlenişi incelenmekte ve etnisitenin neden olduğu nispi gerilimlerin 
yarattığı boşlukları dijital üretimlerle telafi edebilmenin topluluk motivasyonlarına bakılmaktadır. Aşağıdaki alt başlıklarda, çalışmanın amaç ve yöntem dizaynına yer verilmekte, netnografi yönteminin uygulama süreci ve aşamaları anlatılmaktadır.

\section{Amaç}

Bu çalışma Türkiye'de önemli bir dezavantajlı grup olan Romanların sosyal medya üzerinden kimlikleriyle ilişkili düşündükleri olumsal ve negatif/sorunlu kodları ifade ediş biçimlerini, öteki/Roman olmayan ile bağlarını ve mesafelerini kurgulama pratiklerini; Roman Araştırma Merkezi Facebook grubundaki somut kültürel çıktılar özelinde okumayı amaçlamaktadır. Araştırmada ikincil/alt amaç olarak, sosyal medyatik öz-temsilin ve topluluk oluşumlarının öteki kimlikler nezdinde yarattığı işlevsel onarım/telafi durumlarını Roman öz-temsiliyeti vakasında örneklemek düşünülmektedir. Araştırma amaçlarına yönelik olarak şu temel sorulara yanıt aranacaktır;

- Roman Araştırma Merkezi Facebook grubundaki çevrimiçi bireyler tarafından kurgulanmakta olan Roman kimliğinin demografik kodları, topluluk motivasyonları, müşterek amaçları ve denetim mekanizmaları nasıl üretilir?

- Roman Araştırma Merkezi Facebook grubunda kolektif kimlik onarımına/telafisine yönelik öz-temsil faaliyeti neleri kapsar?

- Roman Araştırma Merkezi Facebook grubundaki 'Biz've'Öteki'kimlik tanımları nasıl ve kimleri kapsayacak biçimde kodlanır?

Bu çalışmanın bulguları etnosentrik indirgemecilerin eleştirildiği yeni bir tartışmaya katkı oluşturması bakımından önemlidir. Çalışmayı önemli kılan bir diğer husus ise, suçla ve tekinsizlikle ya da keyfine düşkünlükle ve başı sonu belirsiz eğlence ritüelleri ile itham edilen bir topluluğu, kendi içgörüleri ve özgörüşleriyle anlamaya çalışması; bunu yaparken de dijital kültürün kimlik mücadelesindeki alternatif rollerini göstermesidir.

\section{Yöntem}

Facebook'ta örgütlenen Roman Araştırma Merkezi (2019a) isimli'herkese açık grupta' olup biten öz-temsil olaylarını biçimleyen "iletişimsel eylem kodlarını" (Kozinets, 2002, p. 68) ve onları modellediği içerikleri kültürel birer bulgu olarak irdeleyen bu çalışmada, 
öznel ve özneler arası paylaşımlardaki kültürel kimlik imalatına odaklanılmaktadır. Bu nedenle betimsel yöntemle yapılan bu çalışmada verilere ulaşmak ve analiz etmek için etnografik analizden türeyen netnografik analizle katılımsız gözlem tekniği kullanılarak kategorisel içerik analizi gerçekleştirilmiştir. Netnografi yöntemi Kozinets'e göre (1998, p. 366), sanal topluluklarda giderek daha fazla sosyalleşen çevrimiçi kitlelerin kolektif hislerini, kimliklerini, kültürel üretimlerini, etnik yönelimlerini, dünya görüşlerini, fantezilerini, içgörülerini ve başkalarına ilişkin tutum ve sanal davranışlarını çözümlemeye yarar. Roman Araştırma Merkezi kolektifindeki sosyo-dijital çıktıların kültürel dökümünü çıkarmak için uygulanan yöntemde, yazışmalar, multi-medya paylaşımlar, beğeniler, yorumlar, tüm hareketli ve sabit görseller, sözeylemler ve diğer türden tüm içerik semptomları incelemeye alınarak özgün bir kitlenin etnik kamulaşma biçimleri betimlenmektedir. Bu çalışmada, incelenen toplulukta paylaşılan içerikler yalnızca dijital dokümantasyonlar olarak değil, kültürün temel bağlantılarını kuran semboller sistemi, iletişimci özellikleri ve etkileşim yolakları olarak düğümlenme ve açılmalar ilişkisinde değerlendirilmiştir (Kozinets, 2010a, p. 5).

Sayfa içindeki tüm aksiyonları birer kültürel veri ağı olarak inceleyen çalışmada, veri toplama tekniği olarak katılımsız gözlemden faydalanılmıştır. Sahadaki veri tipolojisini "arşivsel veri ve saha notları" (Kozinets, 2010b, p. 98) olarak yapılandıran katılımsız gözlem pratiğinin verilere ulaşmak için seçilmesindeki temel kıstas, nispeten küçük bir popülasyon içeren özgün grubun çevrimiçi etnik davranışlarına sadık kalmaları için düzenledikleri 'yerlilik' ortamı bozmamaktır. Bunun yanı sıra, topluluk yöneticileriyle yapılan ön görüşmede sürekli 'üye' kaybeden toplulukta kişilerin dışarıdan olanların 'gözetimine' karşı tepkisel refleks gösterme risklerinin yüksek olduğu anlaşılmış ve süreç 'dışarıdan izleme' pratiği olarak katılımsız gözlem şeklinde yürütülmüştür. Bu sayede aksiyonlar içerisinde belirgin bir izle kendini hissettirmeyen araştırmacılar, saha içi gözlemlerinde grup ritüellerine katılım göstermemiştir.

Araştırma sahasında 2019 yılı Temmuz ayı itibariyle 1,116 kişinin üye olduğunu gösteren bir sayfa metriği olduğu hesaba katıldığında, içerik üretimine katılan hedef evrenin sayıca azalması kaçınılmazdır. Nitekim topluluk sayfası 'adanmışlar ve içerdekiler' dışında diğer üyelerin etkileşim halkalarına dahil olmadığı ve kültürel iz bırakmadığı dar etkileşimli bir alanda kurulmaktadır. Yorumlardaki azlığın, genellenebilir bir kültürel okumaya imkân vermemesi nedeniyle içerik etkileşimleri paylaşımlar ve beğeniler sınırlığına alınmıştır. Topluluk sayfasının'tartışma alanına' bakıldığında, kuruluş tarihinden beri kayıtlanan 723 paylaşımın toplamda 67 farklı kullanıcı (yoğunlukla 17 farklı kullanıcı) tarafından paylaşılmış 
olması, yorum kültürünün gelişmemesi ve sayfa içi etkileşimlerin genellikle içeriği'paylaşma' düzeyinde gerçekleşmesi gibi göstergeler öne çıkmaktadır. Bu nedenle doğrudan gözlenebilen ve içeriklerine bakılan katılımcı grubu 67 kişilik paylaşımcılardan oluşmaktadır. Bunun yanı sıra, sayfanın doğrudan öz-paylaşımları ise, kurucu/kullanıcı tarafından paylaşılmaları gerekçesiyle katılımcı grubuna işlevsel katkı oluşturamamaktadır.

Araştırma tasarımı, Kozinets'in (2010b, p. 61), yaygın netnografi uygulamaları için ideal olarak ifade ettiği aşamalı süreçleri referans alarak gerçekleşmiştir. Buna göre, "giriş ve planlama, veri toplama, veri analizi, üye kontrolleri ve araştırma etiğinin sağlanması" aşamalarına uygun bir araştırma dizaynı çerçevesinde hareket edilmiştir. Araştırmanın metodolojik tasarımını ve veri modellemesini gösteren sürecin uygulaması aşağıdaki gibi gerçekleşmiştir;

Giriş ve planlama aşamasında; araştırma sahasında (topluluk sayfası) yapılan sondaj gözlemlerine bağlı olarak öncelikle zamansal sınırlıklar çizilmek istenmiştir. Çünkü çalışma, bir kültür hakkında teorik konuşma yapabilecek kadar kapsayıcl; olağan görünümden sapmayı engelleyecek kadar da odaklı olmalıdır. Bu gerekçeyle inceleme zamanlılığı, topluluk sayfasının açıldığı gün olan 17 Haziran 2016 tarihinden 30 Temmuz 2019 tarihine kadar biriken tarihsel üretimleri kapsamaktadır.

Çalışma sahası olarak seçilen'Roman Araştırma Merkezi', Facebook'taki üye sayısındaki görece yükseklik, paylaşımlarda temsil edilen etnik ve kültürel ilişkilerin çeşitliliği, etkileşim metrikleri ve paylaşım sıklığı gibi kriterlere bağlı olarak çeşitli mukayeseler neticesinde belirlenmiştir. Topluluk popülasyonu az görünse de sosyal medyada Roman kimliğini referans alan etnik gruplar arasında en yükseklerden biridir. Bu durum, Romanların kimlik sorunlarına yönelik ilgilerin boyutlarını göstermesi bakımından da önemli bir ayrıntıyı düşündürmektedir.

Sosyal medyanın Facebook'la sınırlandırılmasında, dünyada en çok kullanılan sosyal medya platformu olması (www.statista.com), topluluk ilişkilerinin sürdürülmesine fonksiyonel altyapı ve ağ mimarisi desteği sağlaması, kültürel arayüz tasarımı bağlamında en uygun sosyo-dijital özellikleri içermesi ve topluluk hesaplarının yoğunlaştığı bir alana dönüşmesi (Özmen \& Keskin, 2018) gibi nedenler etkili olmuştur. Yine buna paralel olarak birçok sosyal medya platformunda yapılan sondaj incelemelerinde Roman kimliğini kolektif olarak ele alan ve telafi kaygılarıyla hareket eden en ciddi oluşumların Facebook'ta olduğu saptanmıştır. 
Öncelikle topluluğun kültürel kimliğinin ve etnik inşasının güzergahındaki kimlik imalatlarındaki özgünlük tespit edilmiş ve bu özgünlüğün topluluk ritüellerine dökülüşlerini anlamayı öngören bir problematik tespit yapılmıştır. Araştırma amaçları ve sorularını içeren bu tespit sonrasında, incelemenin yapılacağı sahayı daha iyi tanımak için sayfa yöneticileri ve bazı kullanıcılarla irtibat kurularak bilgiler alınmış ve araştırma sürecini tamamlayacak bazı öneriler toplanmıştır. Böylece topluluk içindeki Roman kimliğinin özgül ağırlı̆ı hakkında bir tasarım oluşmuş ve içerideki süreçlerin aşinalıkla gözlenmesi kolaylaşmıştır.

Araştırmacılar tüm süreçte kimliklerini ve araştırma amaçlarını açıkça belirterek hareket etmiştir. Sayfa yöneticileri ile görüşülerek araştırmanın kapsamı, konusu, ortaya koymayı hedeflediği bulguları ve önemi hakkında bilgi aktarılmış ve gözlem için izin alınmıştır.

Veri toplama aşamasında; nitel veri toplama tekniklerinden olan katılımsız gözlem gerçekleşmiştir. Facebook zaman tünelindeki tüm topluluk girdileri birer doküman olarak değerlendirilmiştir. Facebook'un zaman tüneli özellikleri ile bir tür kayıtlama/ depolama fonksiyonunu hizmet olarak kullanıcılara sunması, inceleme zamanlılığında esnek gözleme izin vermiştir. Bir ayağı arşiv incelemesi şeklinde gerçekleşen veri toplayış, bazı kültürel hareketlerin teorik bağlamına şerh düşen saha notlarının da desteklediği 'dijital gözlem' süreci olarak da değerlendirilebilir. İnceleme esnasında kimlikle ilişkisi bağlamında kategorilendirilen ve kuramsal art alanları saptanmaya çabalanan içerikler birer kültürel kod olarak değerlendirilmiştir. Sayfa içindeki depolama alanlarında, sayfanın yöneticileri tarafından paylaşılan 147 fotoğraf, 2 video ve 3 etkinlik daveti tespit edilmiştir. Tartışma alanında ise 472 hareketsiz görüntü, 118 video ve 133 yazı odaklı paylaşım olmak üzere toplamda 723 kültürel paylaşım vardır. Screenshot/ekran görüntüsü alma tekniğiyle kayda alınan etkileşim hareketleri, demografik özellikleri, topluluğun denetleyici mekanizmalarıyla olan organizasyonel bağları ve ötekilik ilişkilerinde 'Biz' olanın ayrıcalığına hizmet etme biçimleri gibi kategorisel notların yardımıyla tanımlanmıştır.

Verilerin analizi aşamasında; çalışma sahasından toplanan kültürel kimlik kodları Dey'in betimsel analiz uygulaması (Özdemir, 2010, p. 330) çerçevesinde çözümlenmiştir. Nitel veri analitiğinin etken bir parçası olan betimsel analizi, verileri betimleme, sınıflandırma ve ilişkilendirme aşamalarında uygulayan Dey, ilişkiselliği öne çıkarmaktadır. Roman etnik kimliğiyle ilintili kodlar, denk düştükleri anlamı içerecek şekilde betimlenmiş; 
sahadan alınan öz-temsili kültürel içerikler'(1) demografi, (2) topluluk ağları, (3) Roman kimliğine ilişkin öz-algılar ve kanaatler, (4) Başkasına/Öteki'ne ilişkin betimlemeler ve anlatılar, (5) Roman Kimliği ve Ötekisini ilişkilendirme biçimleri' kategorilerinde (Tablo 1) sınıflandırılmıştır. Her bir kategoride farklı bir betimsel kodları (Tablo 2) üreten paylaşımlar setleri arasındaki teorik ilişkilerin Roman etnisitesiyle ilişkisi de düşünülerek karmaşık bir bağıntılar ağı üzerinde akmakta olan kimliğin görünen sureti anlamlandırıımıştır. Topluluğun kültürel dinamizmi ve akışkan üretim sinerjisi paylaşım içeriklerindeki hareketliliği anlamaya çalışmak üzere tanımlanırken, arşivsel verileri saha notları çerçevesinde açımlayan teorik bir yorumsamadan istifade edilmiştir.

Araştırma etiğinin sağlanması aşamasında; topluluğun iç dinamiklerine ve Romanların hassas oldukları kimlik kabullerine sadık kalan bir perspektif belirlenmiştir. Topluluk sayfasının 'herkese açık grup' olarak devam ettirilmesi nedeniyle sayfada içrek ve dışa açmaktan kaçınılan bir kültürel biçim olmadığı varsayıımıştır. Buna karşın yalnızca Romanlar arasında paylaşılan bazı hassas ve kişisel yorumlar, kimliklere dönük nefret söylemleri ve tahkir edici temsiller kapsam dışı tutulmuştur. Roman kimliği araştırmacıların yargıları dışında tutularak yalnızca sayfa içindeki kültürel içeriklerin gösterdiği haliyle tanımlanmıştır. Sahada karşılığı olmayan hiçbir veri ya da bulgu araştırmada kullanılmamıştır. Araştırmada, topluluk sayfası kurucusu ve sayfa içi aktifliği görünen 'adanmışlar' dışında hiçbir Roman kullanıının kimliği açıkça belirtilmemiştir.

Üye kontrolleri aşamasında ise; tüm üyelerle bire bir görüşme imkanı olmadığı için üye kontrolleri topluluğun sayısal ölçümünü gösteren metriklerle sağlanmıştır. Romanlara has bazı kültürel göstergelerin anlamlandırılmasında üyelere başvurulmuş, araştırmada kullanılan bazı içeriklerin bilimsel yorumlamasında üyelerin görüş ve önerilerinden yararlanmıştır. Roman kimliğine ilişkin tanımlayııı bazı bilgiler için sayfa içindeki referansları doğrulamak adına bazı 'adanmış' üyelere danışılmışır. Sayfa yöneticileri, bazı durumların anlaşılmasında ve statülerin saptanmasında araştırmacılara danışmanlık yapmış ve süreci hızlandırmıştır.

\section{BULGULAR}

\section{Romanları 'Kendi Hallerinde' Anlamaya Çalışmak}

Roman olmanın sosyo-dijital tezahürleri üzerinden kimlik hakkında konuşan bu bölümde, sayfanın demografik özellikleri, toplumsal düzenleyiciler, kimliğe dayalı etnik 
itkiler ve paylaşım ilişkileri serimlenmektedir. Sayfanın adı her ne kadar'Roman Araştırma Merkezi' olarak seçilse de mevcutta formel bir kurumsal nitelik söz konusu değildir. Birkaç Roman vatandaşın kişisel gayretleriyle başlayan toplulaşma hareketi, kamusallaşarak kolektif bir hareketle bütünleşik nizama erişmiştir.

Topluluğun kendini tanımladığı ve öz-kımliği hakkında konuşma yaptığı'hakkında' bölümünde, kuruluş amaçları da çerçevelenmektedir. Hakkında bölümündeki ifadeler şöyle aktarılabilir (Roman Araştırma Merkezi, 2019b):

Grubumuzun toplumsal yaşamın üretkenleşmesi ve farkındalık algısı ve bilgilendirmeye yönelik güncel haberleşme sosyal anlamda paylaşımlarda eleştirisel üslupta objektif her türlü haber bilgilendirmeleri grup yöneticisi tarafından desteklenir paylaşımına izin verilir. Grubumuzun paylaşımcıları ahlaki tutumunu Roman Araştırma Merkezinin onursal olarak insana hizmet esasında görmekle mükelleftir. Her türlü güncel gündem oluşturulan sıcak haber ve paylaşımlarınız Roman Araştırma Merkezinin yöneticisi tarafından değer görülür önemsenir korunur ve desteklenir.

Kendini 'Roman Savunucusu' olarak tanımlayan topluluk yöneticisi, var olduğu sayılan gerilime karşı iddialı bir sıfat benimsemesine karşın, topluluğun işlem alanında 'yumuşak karna dokunmama' gibi bir itidalli tutum da söz konusudur.

Topluluğun görsel kimliğini belirten profil fotoğrafında ise, topluluk yöneticisi tarafından tasarlanan ve tüm dünyadaki Romanları temsil eden 'Mavi-Kırmızı-Yeşil' bayrağın renklerinin kullanıldığı bir tipografiye yer verilmektedir. Sembolik bir anlamla oluşturulan ve lanse edilen profil fotoğrafı, Roman kimliği ile kurulması beklenen ulusal kimlik ve çok kapsamlı temsiliyeti de özetler niteliktedir. Nitekim bayrak simgeseliyle kastedilen hedef kitle, Türkiye ile sınırlı değildir ve dünyanın birçok yerindeki Romanlara hitap eder.

\section{‘ille de Roman Olsun!’: Biz Olmanın ‘Cümbüşünde’ Topluluk Demografisi}

İstikrarlı bir üye profili gözlenmeyen topluluktaki üye sayısı sürekli azalıp artmaktadır. Gruptan ayrılanlar ve yeni üye olanlarla sürekli değişim göstermektedir. Üye profilleri incelendiğinde büyük çoğunluğun erkeklerden oluştuğu görülmektedir. Paylaşım, beğeni ve yorumların da büyük çoğunluğunun erkekler tarafından yapılmaktadır. Bu gösterge, Roman kolektif kimliğinin daha çok hangi toplumsal cinsiyetin kontrolünde 
biçimleneceğini de anlatmaktadır. Topluluktaki kimlik inşaatı, erkek egemen bir dilin anlamsal dolaşımlarına göre yol almaktadır

Topluluk sayfası, Türkiye'nin çeşitli illerinden Romanların yanı sıra; Balkanlar'dan Makedonya, Sırbistan, Hırvatistan, Arnavutluk ve Bulgaristan Romanlarından katılımcılara sahiptir. Bu geniş coğrafya dağı̆ımı nedeniyle de grupta kendiliğinden Türkçe, İngilizce ve Romanca dilleri kullanılmaktadır. Ancak ağırlıklı iletişim dili Türkçedir. Türkçe bilmeyen ya da çok az bilen Balkan Romanları, Romanca veya İngilizceyi tercih etmektedir.

Grup üyeleri genel olarak belli bir eğitim düzeyine ve farkındalığa sahip Romanlardan oluşmaktadır. Genelde Roman sivil toplum kuruluşları başkanları, kanaat önderleri, Roman araştırmalarına ilgili duyan Romanların yanı sıra Roman toplumuna ilgi duyan Roman olmayanlar (büyük çoğunluğu Türk kullanıcı) az sayıda olsa da sayfa içinde temsil edilmektedir. Topluluğun özel ilgi alanı Roman araştırmaları olduğundan Roman kimliğine sahip olmak, 'biz' olmanın ön şartı olarak yorumlanabilir. Toplulukta tersine dönen Azınlık-Çoğunluk ilişkisinde egemen ve başat çoğunluğun ayırt edici niteliği, etnik bir özellik olan Roman kimlik mensubiyetidir. Sayfada bir'öteki' olarak farklılaştıııcı tutumun işletileceği kimlik türü ise, beklenenin aksine tersine işleyen süreçte azınlık haline gelen Türk etnik kimlikli kullanıcılarla sınırlandırılamaz. Ötekileştirmeye yönelik bildiriler, suskunluklar, yaptırımlar, yorumlar ve tepkiler'Gaco'lara yani Roman olmayanlara karşı yapılmaktadır. Romanların kendilerinden olmayan yabancıları tanımlamak için kullandıkları 'Gaco' sıfatı, bir damga türü olarak Roman lügatinde 'kadın' ya da 'zenne' anlamlarını da taşır. Bu damgalayıcı sıfatın aslında Romanların toplumsal cinsiyet meselelerine ilişkin bir ipucu sunduğu ifade edilebilir. Bunun yanı sıra Goffman’ın (2014) damga meselesine ilişkin, 'damgalanan bireylerin de kendilerini damgalayanlara karşı damgalar ürettikleri' teorik önermesi anlam kazanır. Kullanıcıların kendi içlerinde de zaman zaman politik tercihlerindeki farklılıkları ve sahip oldukları alt kimlikleri kullanarak (Dom'lar, Lom'lar Abdal'lar vb.) birbirlerini ötekileştirdikleri bir dile başvurdukları gözlenmiştir.

Topluluğun ortak güdülerinden en belirgin olanı Romanların kendilerine ait toplumsal bir sosyal medya platformu oluşturma, birbirlerinden haberdar olma ve dayanışma çabası olarak belirginleşir. Örselenmiş ve madun kimlik yapılarında görülen en muhtemel eğilim, kendisi gibi olanlarla toplaşmak ve kimlik hasarlarını bir dayanışmanın onarıcı eylemleri içerisinde asgariye indirmektir. Çeşitli ülkelerde diasporik halde bulunan Romanlar, sosyal medyanın ulus/mekan ötesi imkanlarını, kimliği gösterme ve dayanışma 
gerekçelerine dönüştürmektedir. Roman Araştırmaları Merkezi'nin üyeleri arasında çokça gözlenen Roman STK üyeleri/yöneticileri; organik hayattaki dayanışmanın sosyal medyada sürdürülen bir dayanışmayı beslediğini göstermektedir.

\section{Topluluk Güdüleri, Telafinin Vaziyeti ve Kültürel Öz-Temsilin İdare Edilişi}

Roman Araştırma Merkezi Facebook topluluğunun kültürel çıktıları, üye ve yöneticilerin gerçek profilleri ile gerçekleştirdikleri paylaşımlardan oluşmaktadır. Topluluğa dahil olan kullanıcılar içeriklerin üretim aşamasında belirleyicidirler. Yalnızca yönetici merkezli bir paylaşım kültürünün benimsenmemesi, demokrasi ve katılım motivasyonlarının da yüksek ilgiyle hayata geçtiğini ifade etmektedir. Topluluk sayfasında paylaşılan içerik tipleri kategorize edildiğinde şöyle bir sınıflama ortaya çıkmaktadır: Roman Sivil Toplum Kuruluşlarının çalışmaları, kentsel dönüşüm ve Romanlara etkileri, Romanların Türk Toplumuna katkıları, Romanların eğitimi, toplumdaki Roman imajı ve bu imajı düzeltmeye yönelik çabalar, maruz kalınan ayrımcılık ve hakaretler, Romanların iş bulma zorlukları, Roman kimliğinin inşası, AB Roman Projeleri, başarılı Romanlar, dini değerler, özel gün kutlamaları, üyelerin bireysel başarı ve çalışmaları, politika ve politik günceler.

Yukarıda tarif edilen kategoriler, Roman kimliğine mensup kişilerin kendilerine yükledikleri güçlü anlamlar ve algıladıkları sorunlar ekseninde sıralanabilir. Topluluğun Roman kimliği, kimliğin paylaşımcılarının ideal anlam yüklemeleri ile sorun odaklı mücadele setlerinin karşıtlığını barındıran çok yönlü ve gerilimli bir yapıdır. Bu yapıyı kuran ve denetleyen içerikler üyelerin sinerjik eylemlerini koordine etse de merkezi bir disiplin mekanizmasının kontrol davranışı sergilediği görülür. Nitekim bu davranış yazılı bir norm olarak sayfa ifade edilmektedir (Roman Araştırma Merkezi, 2019b)

Her tür uygunsuz ahlaki müstehcen video fotoğraf içeren paylaşım yazılımsal kötü küfür uslu bunu aşan arkadaşlarımıza grup yöneticisine ve üyelerine paylaşımlarına kötü haksız tutum içeren küfürlü söylemlerden Roman Araştırma Merkezi Yöneticisi müdahale eder uyarır veya gruptan çıkartır !..

Sayfa yöneticisine yetkeci bir tutum hakkı tanıyan disiplin gücü, yetkinin kullanım gerekçesini 'kamu yararı' ve 'genel ahlak' kriterleri çerçevesinde olağan bir tanıma büründürmektedir. Sayfa yöneticisi, topluluğun düzen için yetkiyi devrettiği temsili yönetsel oganizmanın da somut bir görünümüdür. Sayfa yöneticisi Roman kimliğinin üyeler tarafından nasıl kurulacağına pek fazla karar veremese de'nasıl kurulamayacağına' 
karar verebilme yetkisini kullanabilir. Bu yetki bir eşik bekçiliği statüsü ile birlikte sayfa yöneticisinin içeriklere editöryal müdahalede bulunabilme özgürlüğünü de kapsar.

Topluluk sayfasındaki Roman kimliği dönemsel gündem başlıklarına ilişkin olarak farklı kamusal müzakereler çerçevesinde kurulur. Sözgelimi Roman açılımından sonra Avrupa Birliği'nden Roman sivil toplum kuruluşlarına verilen destekler ve bu desteklerin olumlu sonuçları tartışıııken bu desteklerin hangi Roman sivil toplum kuruluşlarını kapsadığı, bu paranın nasıl paylaşıldığı ve nerelere harcandığı da konuşulmaktadır. "Yardımlaşma ve AB'den Gelecek 4.5 Milyon Euro" (Acar, 2018) gibi paylaşım başıkları altında tartışılan meseleler, bazen bir iç muhasebeye dönüşerek sivil toplum kuruluşlarının etkinliğini sorgulamaya ve eleştirmeye kadar uzanır. Hangi sivil toplum kuruluşunun gerçekten Roman toplumunu düşündüğü ve söz konusu destekleri amaca uygun kullandığı platformda sıkça yapılan tartışmalar arasındadır.

Topluluk gündemlerinde bir taraftan'yardıma muhtaç bir toplum'imajını güçlendiren yoksunluk parametreleri öne çıkarken, diğer taraftan başarının sağlayacağı imajın da kaygısı güdülmektedir. Roman kimliğinin topluluk içindeki en ideal işlemlerinden biri, bireysel ya da kolektif, ulusal ya da uluslararası başarılardan feyiz almaktır. Topluluk içerisinde Roman olmaktan ve Roman kültüründen duyduğu gururu ve fırsat verildiğinde çok iyi işlere imza atabileceğini vaat eden çok sayıda kullanıc ilk bakışta görülebilir. Başarıların paylaşımı bir müjde havasında ve asli görev ciddiyetiyle yapılmaktadır. Örneğin, "Macaristan’ı Eurovision'da Roman Müzisyen Temsil Ediyor" (Ilgın, 2017b) başlıklı paylaşımdaki etkileşimler incelendiğinde, Roman şarkıcının uluslararası bir yarışmada yer alması, sadece Macaristan'daki Romanların değil bütün Romanların başarısı ve gururu olarak addedilmektedir. Bu başarı hikâyesi üzerinden Türkiye özelinde öz eleştiriler üretilmekte ve bir anlamda cesaret ve özendirme performansı ortaya konmaktadır.

Topluluktaki Roman kimliği olumlama taktikleri arasında kanaat önderlerinin övgülerini ve tespitlerini öne çıkarma yaklaşımı önemli yer tutar. Örneğin, "Avrupa'da ve Balkanlarda Çingeneler olmasaydı Türkçe yabancı ülkelerde yaygınlaşamazdıHocaların Hocası İlber Ortaylı" (Ilgın, 2017a) paylaşımı, kaynağının doğruluğu sorgulanmadan bir övünç durumuna devşirilmektedir. Bu paylaşıma yapılan yorumlarda destekleyici görüşlerin yanı sıra Çingenelerin Türkçe konuştukları için kendi dillerini kaybettiklerini belirten ve bunun kendi açılarından pek övünülecek bir durum olmadığını vurgulayan 'milliyetçi' görüşler de yaygındır. 
Topluluk sayfasında Roman kimliğine olumsal kodlar yükleme pratiğinin en sık görüldüğü kültürel örüntüler arasında eğitim odaklı paylaşımlara da özel bir yer açmak gerekir. Eğitimsizlikle itham edilen bir kimlik grubunun kimlik vurgularını bu odakta yoğunlaştırması olası bir durumdur. Sık sık paylaşılan burs programları, Roman kimliğinden emin ve gururlu, yüksek eğitimli, sosyal ve akademik açıdan başarılı gençlerin yetişmesinin çok önemsendiği bildirimleriyle birlikte imaj tasarımına dönüşmektedir. Topluluktaki Romanların eğitim konusundaki bir diğer övünç noktası ise, içlerinden çıkan yüksek mertebeli meslek sahipleridir. "Eğitimcilerin değeri sıfır. Olsun, hakim olmuş, doktor olmuş, öğretmen olmuş Romanlar var" (Elbasan, 2018) tarzındaki paylaşımlar, fırsat verildiği, eşitlik ve adalet sağlandığı taktirde Romanların yüksek eğitim gerektiren mesleklerde var olabileceği yorumlarılla desteklenmektedir. Roman olma halinin içinde bulunduğu buhran ve bunalımlara kaynak olarak kimlikler arası eşitsizlik ve ayrımcılığın yakıt olduğu bilinci Roman kimliğini kurması beklenen kitlenin tutumunu belirlemektedir.

Toplulukta Roman kimliğini imaj ve kanaat olarak beslemesi düşünülen ilgin bir diğer mesleki ayrıntı ise çiçekçiliktir. Toplumda yaygın kanı olarak Romanların çiçekçilikle geçindiği tahayyülünün yerleşmesi, Romanları rahatsız eden bir durum olmanın ötesinde övünç kaynağı olarak ön plana çıkmaktadır. İstanbul Roman Çiçekçiler Derneği'nin "Çiçek Bizim İşimiz" sloganıyla mesleklerini "Romanların Plaketi” saymaları, sayfa içinde yüksek etkileşim alan ve olumlu karşılanan bir harekettir. Bu durum, geleneksel medyadaki klişe tiplemenin Romanlar nezdinde hegemonik kabuller oluşturduğu ve kendi ekonomisini yarattığı şeklinde yorumlanabilir.

\section{Ötekisi ile Birlikte Roman Kimliği: “Biz Romanlar, Siz Gacolar”}

Topluluk paylaşımları Roman kimliğini Türkiye'deki en büyük dezavantajlı ve ötekileştirilen temsil kategorisi olarak tanımlarken öte yandan Romanların ülkenin asli unsurlarından biri olduğunu ve Cumhuriyetin kurucu değerlerinin yanı sıra, sembolik değerlere (bayrak, vatan, devlet vs.) ve tarihe karşı sadakat geliştirdiklerini belirtmekte, sürekli hatırlatmaktadır. Bu hatırlatmanın bir şekilde dışarıya seslenen ve Türk etnik kökenli vatandaşları hedefleyen mesaj özellikleri olduğu ifade edilebilir. Sayfa içinde Türk kimliğine bağlılığın - ki bağlılık ifadesi sadakat ve parçası olma anlamlarını eşgüdümlü karşılar- en popüler gösterenleri, 'Bayrak've 'Mehmetçik' imgesine yönelik sevgi ve saygı ünlemleridir. Bu kolektif davranış konusunda tepki gösteren, aksi beyanda 
bulunan bir kullanıc yorumuna ve paylaşımına rastlanmamıştır.

Topluluktaki Roman kimliğinin hangi 'Biz' momentinde merkezileşeceği konusunda bir ayrım düşünüldüğünde, Türk ulus kimliği ile Roman etnik kimliğini eklemlemeyi amaçlayan bir niyet anlaşılabilir. Topluluktaki Romanlar, toplumun genelinde gözlendiği gibi Türk ulus kimliğinin parçası olarak seçkinliği ve Roman olarak öz-aidiyeti aynı potada idare etmeyi denemektedir. Bunun için internette dolaşan popüler bir görsel üzerinde ufak rötuşlar yaparak etnisite kaynaklı farklııı̆a ve birlikteliğe eşzamanlı vurgu yapılmak istenmiştir (Görsel.1).

Toplulukta Biz'in çoğulluğuna ve seçkinliğine karşılık bir öteki arandığında ya da imal edilmek istendiğinde,'sen'ya da 'o' tekilliğinin seçilmesi tesadüf değildir ve kitlesel güdülenmeyi vurgular. 'Biz' ve 'öteki' ayrımı sayfadaki paylaşımların ekseri kısmında görülmektedir. Öteki olanın gizil kaldığı söylemlerde'Romanları dışlayan, hor gören ve tahkir eden' anonim bir cenah kastedilse de açık seçik konuşmalarda öteki olanın adı ile çağrılmasında hiçbir sakınca bulunmaz: 'Gaco'. Gacolar yani Roman olmayanlar, topluluğun kimlik temelli faaliyetlerinde çoğu kez Romanları aşağılayan, Roman kültüründen bihaber, eşit vatandaş bakışından uzak, yeri geldiğinde kendi çıkarları için Romanları kullanan, günlük hayatlarında veya özel durumlarda Romanlardan söz ederken nefret söyleminde bulunan ve ötekileştirici bir dil kullanan, Romanlardan özür dilemesi gereken kişiler olarak tanımlanmakta ve temsil edilmektedir.

'Biz Romanlar, Siz Gacolar' ifadesi, Psikolog Derya Koptekin'in (2017) İzmir'deki Roman çocukların kimlik inşası üzerine yazdığı bir araştırma kitabının ismidir. “Türkiye'nin ötekilerinden olan Çingene/Romanlar, kendi kimliklerini hangi ötekiler üzerinden kuruyor, toplumsal hiyerarşide kendilerini nasıl konumlandırıyorlar? 'Gacoların' hep teğet geçtiği, baktığı ama görmediği Romanların dünyasını anlatan bir çalışma"tanıtım yazısıyla paylaşımı bir kaç kez tekrarlanan kitap, karşılıklı ötekileştirmeye vurgu yapması ve sayfa içindeki öteki üretimine akademik taban oluşturacak şekilde argümana dönüştürülmesi bakımından önemlidir.

Romanların ötekileştirmeye maruz kaldıkları ve diğer azınlık etnik kimliklerle ortak kader paylaştıklarına ikna olduklarını çocukluk dönemi psikolojik travmaları ve kimliklenme süreçleriyle açıklayan kitabın topluluk pratiklerinde somut karşılıklarını görmek mümkündür. Çünkü kitaba göre Roman çocuklar ayrımcılığı ve dışlanmayı öğrenerek büyür, sonucunda ise öteki olmayı sindirir. Toplulukta paylaşılan bir görselde, 
Roman olduğuna inanılan bir gencin müşkül durumda bulunan ve dilenci olduğuna inanılan kişiye yardım ettiği anın hikayesi üzerinden imaj üretilirken; "sen bizdensin demiş Roman Kardeşimiz" başlığının kullanımı dikkat çekicidir. Bu ifadeleştirme tarzı, topluluktaki Romanların kendileri gibi dezavantajı gördükleri kişi ve gruplarla özdeşleşme eğiliminde oldukları ve'yoksulluğu' bir sınıfsal ayrım olarak kabullendikleri (Koptekin, 2017, pp. 49 -118) önermesini doğrular.

Topluluk üyeleri, Gacoları ötekileştirmekle birlikte içlerinde bulunan farklı grupları, kendini farklı katmanlarda gerçekleştirmiş kişileri de ötekileştirme eğilimi gösterir. Kimliğin kurulmasında politik kutuplaşmaya bağlı hizip hareketleri ya da taraf olmalar belirgin hale gelir. Kimliğin siyasetle yakın ilişkisi beraberinde içerden ötekileşmeyi ve karşılıklı yabancılaşma ithamlarını getirir. Özellikle kimin daha gerçek Roman olduğu, toplum liderliği yarışı, efsaneleşen Roman projeleri, Adalet ve Kalkınma Partisi ve Cumhuriyet Halk Partisi üzerinden yapılan çatışmacı paylaşımlarda herkes kendi partisinin ya da kendi sivil toplum kuruluşunun Romanlara en iyi hizmeti götürdüğünü, götüreceğini savunmaktadır. Kimlik, tanınma ve temsiliyet sorununun çözümüyle ilgilendiğini savunan kamular arasındaki çatışma durumu, öteki kimliklerin içeriden ve daha güçsüz olanları günah keçisi seçme ritüeline neden olur.

Roman kimliğinin topluluk içerisinde temsil edilen en önemli sorunları arasında tanınma problemleri gelir. Bu sorunun gündelik tezahürlerindeki yaptırımlar ise çalışma hayatındaki eşitsizlik, barınma ve prekarizasyon sorunlarıla birlikte daha belirgin hissedilir. Topluluktaki sorun odaklı ifade kalıpları, Romanların işe alınma konusunda kendilerine yapılan ayrımcılığın sona ermesine ve barınma koşullarına yönelik taleplerini, ötekileştirilme tarzlarını içermektedir. Bu taleplerin bir kimlik türünü modellediği düşünüldüğünde, topluluk üyelerinin kendilerini yıllarca uğradıkları ötekileştirme, eğitim, barınma, sağlık, iş edinme imkânlarından yoksun bırakılmışlıklarının sona ermesi için mücadele eden bir grup olarak görmeleri tesadüf sayılmaz.

Topluluk sayfasında temsil edilen en önemli kimlik sorunları arasında, geleneksel medyada Roman merkezli söylemler ve temsillerin yarattığı kültürel erozyon durumu parmakla gösterilebilir. Beşiktaş Kulübü Basın Sözcüsünün Romanları/Çingeneleri hedef alan pejoratif sözlerine ve Evleneceksen Gel isimli realite programda Romanlarla ilgili bir ilişki senaryosuna yönelik olarak "Romanları magazin malzemesi yapamazsınız" (Ilgın, 2016) isimli açıklama paylaşılması ve bu tür gündemler üzerine konuşmalar gerçekleşmesi temsiliyet sorununun ehemmiyetini gösterir. Üstelik bu tarz konuşmalar, 
paylaşımlar ve yorumlar yalnızca tepki içermez; aynı zamanda Romanları kimin temsil edip edemeyeceğini de kapsar. Roman topluluk üyelerine göre televizyonlardaki Romanlar gerçek değildir ve Roman kimliği 'gerçek' Romanlar tarafından temsil edildiğinde gerçek refahını ve anlamsal karşılığını bulacaktır. Üyeler, geleneksel ve sosyal medyada Roman kimliğine karşı bilinçli bir operasyon yapıldığında hemfikirdir. Sosyal medyadaki bu küçük çaplı direnişin motivasyonu da genel olarak olumsuz temsile ve kötü göstermeye karşı bir savunu mekanizması geliştirmekten türemektedir.

\section{TARTIŞMA VE SONUÇ}

Bu çalışmanın problematik kaplamına ve odaklandığı konuyla doğrudan ya da dolaylı ilgisi olduğu düşünülen bir dizi araştırmaya bakıldığında, Roman kimliğini sanal topluluk, öz temsil ve sosyo-dijital telafi ilişkisinde sosyal medyayla birlikte ele alan bir çalışma saptanamamıştır. Buna karşın Condon ve diğerleri (2019), sosyal ağ gezginliğinin oluşturduğu fırsatların, eşitsizlik ve dezavantajlar karşısında Roman kimliğine engelleri aşma gücü verdiğini saptamaktadır. Bu çalışmayla dolaylı ilgisi bulunan bu tanı, mevcut bulgularla tanıtlanmaya çalışılan'sosyo-dijital telafi' faaliyetini destekleyen bir argümandır. Shridevi ve Govindaraju (2018) ise, ana akım toplumdaki anlamların paylaşıldığı sosyal ağlara katılan Roman kullanııların, etnik özelliklerini kaybederek yaygın yaşam stillerine adapte olduklarını savunmaktadır. Ancak bu çalısmayla söz konusu argüman arasındaki fark, araştırılan grubun demografik olarak Roman olduğunu ifade eden kullanıcılardan oluşması ve kültürel paylaşım ritüellerinin etnik tabanlı olmasıdır. Bu durumda etnik bağların kuvvetlendirilmesi ve sürdürülmesi, daha da ileride olumsal kimlik jeneriklerinde ve telafi düzeneklerinde kullanılması güçlü bir topluluk güdüsü oluşturabilir. Oleaque (2019) ise, sosyal ağlarla birlikte artan amatör gazetecilin Roman kimlik sunumlarını bireyselleştirdiğini bulgular. Bu bağlamda, Roman Araştırma Merkezi topluluk sayfasında görünen etnik kimlik inşaları da üreticisinin yaklaşımlarını taşıması itibariyle oldukça bireyseldir. Bu bireyselliğin önemi ise, kolektif paylaşım ağında kamusallaşma konusunda istekli insanlar tarafından paylaşılabilir olmasından kaynaklanmaktadır.

Literatürde Roman kimliğinin temsil biçimini sosyal medyayla ilişkili ele alan çalışmalarda, her zaman onarıcı ya da iyileştirici bir takım etkiler tartışılmaz. Aynı zamanda sosyal medyada Romanlara yönelik yeniden üretilen eşitsizlikler (Cemlyn et al., 2009) ve nefret söylemleri (Alp, 2016) de bu alandaki çalışmaların saptadığı negatif bulgulardır. Kimliklerin mücadele ettikleri, çarpıştıkları ve gerilimlerle yeniden inşa edildikleri sosyal medya, Roman kimliği açısından sosyo-dijital telafiye ve onarıma/ 
iyileşmeye aracılık ettiği gibi, yıpranmaya, zedelenmeye ve yıpranmaya da neden olabilir.

Roman Araştırma Merkezi Facebook topluluğu, diğer sanal toplulukların aksine hoş vakit geçirmek ve ortak özel ilgi alanlarına sahip kişilerden oluşan bir topluluktan daha öte anlam ifade etmektedir. Toplumun madunları olarak tanımlanabilecek Romanların, kendi toplumsallığını inşa ettiği ve gösterdiği bir sosyal yapı, birbirlerine seslerini duyurdukları bir platformdur. Bu platformun genel kültürel çerçevesini anlama amacıyla tasarlanan ilk araştırma sorusunun karşılığındaki bulgular, buradaki demografik yapılanma, toplanma motivasyonları, paylaşım ritüelleri, müşterek amaçlar ya da toplumsal düzenleyicilerin Türkiye'deki diğer dezavantajı/öteki kimlik gruplarının sosyo-dijital aktiviteleriyle benzerlikler taşıdığına işaret eder (Özmen, \& Keskin, 2018; Göker, \& Keskin, 2016). Topluluk görünüşüne göre sosyal medya çevrelerinde toplanmanın/bir araya gelmenin öteki kimlik grubu olarak Romanlar açısından önemi, 'kendisi gibi olanlar' kategorilerinden birileriyle dayanışarak telafiyi gerçekleştirme, normalleşme ve çoğunluğu kurma düşüncesidir. Tüm motivasyonlar, ritüeller, paylaşım ilişkileri, toplumsal normlar bu düşünce momentinde farklı evrelere konumlanır.

Araştırmada yanıt aranan öz-temsilin neleri kapsadığı sorusunu yanıtlayan bulgulara göreyse, bu dijital toplumsallıktaki öz-temsil edimleri bir medya platformu, bir forum gibi de işlemekte ve alternatiflerini üretebilmektedir. Bu anlamda Roman Araştırma Merkezi üyelerinin öz temsilleri yalnızca kültürel sunumu ve kimlik jeneriğini baz alan sosyal içerik ve etkileşimli görsellerle sınırlı bir paylaşım seti olmakla kalmayıp formel haberlerin, organizasyon duyurumların, halkla ilişkiler faaliyetlerinin, imaj restorasyonunun, izlenim denetimlerinin, kurumsal politikaların, örgütlenme ilişkilerinin, Romanları ilgilendiren konularda haberleşmenin ve düşünce paylaşımlarının gerçekleştiği bir temsili kamusallık özelliği taşır.

Öz-temsil kapsamında incelenen Roman Araştırma Merkezi'ndeki kimlik inşaatı 'pozitif' bir kurucu eylem olmaktan daha ziyade, kolektif bir telafi ve restorasyon faaliyetli olarak düşünülmelidir. Çünkü bu toplulukta olup bitenlerin konsepti ve ana fikri, fark edilmeyen bir aklanma çabasından izler taşır. Roman olmakla birlikte toplum tarafından yöneltilen suçlamalara karşı dijital bir arınma zinciri ve suçsuzluğun ispatları kurgulanmaya çabalanır. Romanların bu toplulukta yapmakta oldukları şey, kendilerini 'oldukları gibi' anlatmaktan çok daha fazlası olarak başkaları tarafından 'itham edildiği gibi olmadıklarını' anlatmaktır. Sosyal medyada kendileri hakkında konuşmak için şans elde eden Roman kullanıcılar esasen kendilerini anlatmalarına firsat vermeyen bir savunma sosyo- 
psikolojisiyle refleks göstermektedir. Topluluktaki aksiyonlardan yola çıkarak, Romanların tahkir edildikleri kimlik kodlarının baskısını karşı temsile dönüştürdüğü ve sorunlarını medyada yansıtılmayan biçimlerde dile getirip yeğledikleri karşı imajı kurmayı denedikleri ifade edilebilir. Bu durumda topluluk üyelerinin, medyanın görmezden geldiği olumsal kimliklerini özgürce sergileyerek bir anlamda enformatik boşluğu kapatıp sorunlarına karşı bir farkındalık yaratmayı sürdürdükleri de savunulabilir.

Araştırmada yanıt aranan 'Biz' ve 'Öteki' kimliğini tanımlama pratiklerini açıklamayı amaçlayan soruya ilişkin bulgular arasında ise, toplulukta Romanların öz-temsili kadar, Roman olmayanların temsili konusu da dikkate değer bir olay olarak öne çıkmaktadır. Bu durumda bir Türk etnik kimlikli kişi ya da dünyadaki diğer tüm kişiler, hem Romanların dostu, Biz'in parçası hem de Gaco olma potansiyelini taşır. Topluluğun en belirgin ve topluluk tavırlarının yönlendirildiği ötekisi olarak Türkiye'deki Gacolar, kaçınılmaz şekilde Türk etnik kimlikli kişilerin yoğunluklu olduğu bir gruptur. Esasında tüm öteki kimlikler gibi Gacoları net biçimde tanımlayan, isim veren ya da onları betimleyen bir belirteç yoktur. Onlar Romanların belli belirsiz ve her an, her yerde olan düşmanlarıdır. Bu düşmanın tek belirgin özelliği 'Roman olmaması', yani bir yabancı ya da 'öteki' olmasıdır.

\section{KAYNAKLAR}

Acar, F. (2018, April 12). Yardımlaşma ve AB'den gelecek 4,5 milyon euro [Facebook Status Update]. Retrieved from https://www.facebook.com/groups/253556578354156/search/?query=AB\%27den\%20gelecek\%20 4\%2C5\%20\&epa=SEARCH_BOX).

Akgül, Ö. (2006). Türkiye müzik piyasasında roman müzisyenler: meslekîörgütlenme ve kimliksel dönüşüm (Master's

Dissertation, Istanbul Technical University, Istanbul) Retrieved from https://polen.itu.edu.tr/ bitstream/11527/12602/1/415031021.pdf.

Akgül, B. (2010). Türkiye Çingenelerinin politikleşmesi ve örgütlenme deneyimleri. Öneri, 9(34), 213-222. Akıncı, M. A. (2014). Fransa'daki Türk göçmenlerin etnik ve dini kimlik algıları. BILIG, 70, 29-58.

Alp, H. (2016). Çingenelere yönelik nefret söyleminin Ekşi Sözlük'te yeniden üretilmesi. ILEF, 3(2), 143-172.

Aytaç, A., M. (2017). Bir Türk'ü nereden tanırsınız. Gazeteduvar.com. Retrieved from https://www.gazeteduvar. com.tr/yazarlar/2017/11/13/bir-turku-nereden-tanirsiniz/.

Baker, U. (2017). Beyin ekran. İstanbul, Turkey: İletişim Yayınları.

Baudrillard, J. (2015). Şeytana satılan ruh ya da kötülüğün egemenliği (O. Adanır, Trans.). Ankara, Turkey: Doğu-Batı Yayınları.

Bauman, Z. (2009) Sosyolojik düşünmek (A. Yılmaz, Trans.). İstanbul, Turkey: Ayrıntı Yayınları. Berger, J. \& Mohr, J. (2011). Yedinci adam (S. Sökmen, Trans.). İstanbul, Turkey: Agora Kitaplığı 
Bouerdieu, P. (1989). Social space and symbolic power. Sociological Theory, 7(1), 14-25. DOI: 10.2307/202060

Cemlyn, S., Margaret, G., Sally, B., Matthews, Z. \& Whitwell, C. (2009). Research Report: inequalities experienced by Gypsy and traveller communities: a review. Retrieved from https://www.equalityhumanrights.com/sites/ default/files/research_report_12inequalities_experienced_by_gypsy_and_traveller_communities_a_ review.pdf.

Condon, L., Bedford, H., Ireland, L., Kerr, S., Mytton, J., Richardson, Z. \& Jackson, C. (2019). Engaging Gypsy, Roma, and traveller communities in research: maximizing opportunities and overcoming challenges. Sage Journals, 29(9), 1324-1333.

Connolly, W. E. (1995). Kimlik ve farklılık (F. Lekesizalın, Trans.). İstanbul, Turkey: Ayrıntı Yayınları.

Corner, J. (1995). Television and public address. London, UK: Edward Arnold.

Dişli, S. Ö. (2016). Çingene mi? Roman mı? bir inşa süreci. AÜDTCF Antropoloji Dergisi, 31, 97-117.

Donath, J., S. (1998). Identity and deception in the virtual community. In P. Kollock \& M. Smith (Eds.), Community in Cyber Spaces. London, UK: Routledge.

Enli, G., S., \& Thumim, N. (2012). Socializing and self-representation online: exploring Facebook. Observatorio Journal, 6(1), 87-105.

Elbasan, A. (2018, 18 Kasım). Kanal T izledik sorular sorduk yanıt yok. Olsun hakim olmuş, doktor olmuş öğretmen olmuş romanlar var [Facebook Status Update]. Erişim Adresi: https://www.facebook.com/ groups/253556578354156/search/?query=e\%C4\%9Fitimcilerin\%20de\%C4\%9Feri\%20 s\%C4\%B1f\%C4\%B1r\&epa=SEARCH_BOX).

Facebook Kullanım Verileri. (2019, November 25). Statista. Retrieved from https://www.statista.com/ statistics/272014/global-social-networks-ranked-by-number-of-users/.

Goffman, E. (2014). Damga: örselenmiş kimliğin idare edilişi üzerine notlar (Ş. Geniş et al., Trans.). Ankara, Turkey: Heretik Yayınları.

Göker, G. \& Keskin, S. (2016). Sosyal medyada topluluk ilişkileri: Karikateist Facebook topluluğu üzerine bir araştırma. Akademik Sosyal Araştırmalar Dergisi, 22, 88-108.

Hall, S. (1997). The work of representation. In Stuart Hall (Ed), Representation: Cultural Representations and Signifying Practises (pp. 13-74), London, UK: Sage Publications.

Hall, S. (2017). Temsil: kültürel temsiller ve anlamlandırma uygulamaları (İ. Dündar, Trans.). İstanbul, Turkey: Pinhan Yayıncılık.

Ilgın, C. (2016, December 31). Romanları magazin malzemesi yapamazsınız [Facebook Status Update]. Retrieved from: https://www.facebook.com/groups/253556578354156/search/?query=magazin\%20\&epa=SEARCH_ BOX

Ilgın, C. (2017a, August 12). Avrupa Balkanlarda Çingeneler Olmasaydı Türkçe Yabancı Ülkelerde Yaygınlaşmazdı Hocaların Hocası İlber Ortaylı [Facebook Status Update]. Retrieved from https://www.facebook.com/ groups/253556578354156/search/?query=hocalar\%C4\%B 1 n\%20hocas\%C4\%B1\%20ilber\%20 ortayl\%C4\%B1\&epa=SEARCH_BOX) 
Ilgın, C. (2017b, May 12). Macaristan’ı bu sene Eurovision'da Roman müzisyen Joci Papai temsil ediyor! Şarkı sözlerinde ayrımcılığa vurgu yapılırken, şarkıda geleneksel Roman müziği ve Romanes de kullanılıyor [Facebook Status Update]. Retrieved from https://www.facebook.com/groups/253556578354156/ search/?query=macaristan\%27\%C4\%B1\&epa=SEARCH_BOX

İlhan, S., \& Fırat, M. (2017). Bir inşa süreci olarak çingenelik: kuramsal bir çözümleme. Fırat Üniversitesi Sosyal Bilimler Dergisi, 26(2), 265-276.

James, D. J. (2017). Transnational religious movements: faith's flows. California, USA: Sage Publications.

Jenkins, H. (2006). Convergence culture: Where old and new media collide. New York, USA: New York University Press.

Karan, U. (2017). Görmezlikten gelinen eşitsizlik: Türkiye'de Romanların barınma ve eğitim hakkına erişimi. Uluslararası Azınlık Hakları Grubu (MRG). Sıfır Ayrımcılık Derneği.

Kolukırık, S. (2008). Türkiye'de Rom, Dom ve Lom gruplarının görünümü. Hacettepe Üniversitesi Türkiyat Araştırmaları Dergisi, 5(8), 143-153.

Koptekin, D. (2017). Biz Romanlar siz gacolar. İstanbul: Illetişim Yayınları.

Kozinets, R. V. (1998). On Netnography: initial reflections on consumer research investigations of cyberculture. Advances in Consumer Research, 25, 366-371.

Kozinets, R. V. (2002). The field behind the screen: using netnography for marketing research in online communities. Journal of Marketing Research, 39(1), 61-72.

Kozinets, R. V. (2010a). Netnografi: pazarlamacının gizli silahı. Retrieved from http://kozinets.net/wp-content/ uploads/2012/01/netnography-turkish.pdf

Kozinets, R. V. (2010b). Netnography: doing ethnographic research online. London, UK: Sage Publications.

Levinas, E. (1998). Humanism of the other. Illionis, USA: University of Illionis Press.

Manovich, L. (2001). The language of new media. Massachusetts, USA: MIT Press.

Marsh, A. (2008). Etnisite ve kimlik: Çingenelerin kökeni (Ebru Uzpeder et al., Trans.). İstanbul, Turkey: Mart Matbaacılık.

McLuhan, M. (1962). The Guttenberg galaxy: the making of typographic man. Toronto, Canada: University of Toronto Press.

Mead, G., H. (1934). Mind, self and society. Chicago, USA: University of Chicago Press.

Musse, M. F. (2016). Photography on Instagram: self-representation, Identity and new ways of sociability (Doctoral Dissertation, The University of Pompeu Fabra, Barcelona). Retrieved from https://www.tdx.cat/bitstream/ handle/10803/401385/tmfm.pdf?sequence=1\&isAllowed=y.

Nişancı, Ş., \& Işık, C. (2015). Etnisite kavramının ideolojik serüveni. Kafkas Üniversitesi iiBF Dergisi, 6(9), $195-224$.

Oleaque, J. M. (2019). The representation of Gypsies in the media. Retrieved from https://www.accioncultural.es/ virtuales/vidasgitanas/pdf_eng/vidas_git_art2_representacion_eng.pdf

Oran, B. (2010). Azınlıklar. Retrieved from https://baskinoran.com/makale/Azinliklar-BaskinOran-IstAnsiklopedisi.pdf.

Oran, B. (2014). Azınlıklar nasıl azınlık oldu?. In Yasemin İnceoğlu \& Savaş Çoban (Eds.), Ötekiler ve Medya (pp. 1750). İstanbul, Turkey: Ayrıntı Yayınları. 
Özdemir, M. (2010). Nitel veri analizi: sosyal bilimlerde yöntembilim sorunsalı üzerine bir çalışma. Eskişehir Osmangazi Üniversitesi Sosyal Bilimler Dergisi, 11(1), 323-343.

Özmen, S., \& Keskin, S. (2018). Sosyal medyada öz-temsil ve ötekiliğin 'öteki' boyutu: Karikateist toplumsalı üzerine inceleme. IntJCSS, 4(2), 533-558.

Perkins, T. (2000). On friendship. Cambridge, UK: Polity Press.

Posos-Devrani, A., E. (2017). Medyada 'öteki'nin temsili: etnik komediler. Gümüşhane Üniversitesi Iletişim Fakültesi Elektronik Dergisi, 5(2), 926-949.

Rettberg, J. W. (2017). Self-representation in social media. In J. Burgess, A. Marwick, \& T. Poell (Eds.), Sage handbook of social media. California, USA: Sage Publication. Retrieved from https://www.researchgate.net/ publication/305073320_Self--Representation_in_Social_Media.

Rheingold, H. (1994). A Slice of life in my virtual community. In L. M. Harasim (Ed.), Global Networks: Computers And International Communication (pp. 57-80). Cambridge: MA: MIT Press.

Roman Araştırma Merkezi (2019a, November 24). Facebook. Erişim Adresi: https://www.facebook.com/ groups/253556578354156/.

Roman Araştırma Merkezi (2019b, November 24). Hakkında [Facebook Status Update]. Retrieved from https:// www.facebook.com/groups/253556578354156/about/.

Seber, H. (2013). Queen Elizabeth's self-representation thorough the Petrarchan convention. Hacettepe Üniversitesi Edebiyat Fakültesi Dergisi, 30(1), 227-238. Retrieved from https://dergipark.org.tr/download/article-file/616299.

Shridevi, S., \& Govindaraju, P. (2018). Influence of social media among Gypsies: a case study in Tamil Nadu. IJREAM, 4(4), 492-496.

Taylor, C. (2005). Tanınmanın politikası, çokkültürcülük (Y. Salman, Trans.). İstanbul, Turkey: Yapı Kredi Yayınları.

Uzpeder, E., Roussinova, S., D., Özçelik, S., \& Gökçen, S. (2008). Biz buradayız: Türkiye'de Romanlar ayrımcı uygulamalar ve hak mücadelesi. İstanbul, Turkey: Mart Matbaacılık.

Wacquant, L. (2011) Kent paryaları, ileri marjinalliğin karşılaştırmalı sosyolojisi (M. Doğan, Trans.). İstanbul, Turkey: Boğaziçi Üniversitesi Yayınevi.

Wellman, B., \& Gulia, M. (1999). Net surfers don't ride alone: virtual communities as communities. In P. Kollock \& M. Smith (Eds.), Communities as Cyberspace (pp. 1-26). New York, USA: Routledge.

Wellman, B., Janet, S., Dimitrova, D., \& Garton, L. (1996). Computer networks as social networks: collaborative work, telework, and virtual community. Annual Review Social, 22, 213-238.

Yalçıner, R. (2014). Etnisite ve milliyetçilik: eleştirel bir değerlendirme. Ankara Üniversitesi Siyasal Bilimler Fakültesi Dergisi, 69(1), 189-215.

Yanıkdağ, T. (2012). Türkiye'de yaşayan Romanların sorunları: Genel bir bakış. In L. Ürer (Ed.), Roman olup Çingene kalmak. İstanbul, Turkey: Melek Yayınları.

Žižek, S. (2006). The parallax view. Massachusetts, USA: MIT Press.

Žižek, S. (2019). Yamuk Bakmak (T. Birkan, Trans.). İstanbul, Turkey: Ayrıntı Yayınları. 


\section{TABLOLAR VE GÖRSELLER}

Tablo 1: Sahadaki Paylaşımların Kategorisel Analiz Verileri

\begin{tabular}{|l|c|}
\hline Kategoriler & Frekans/Yüzde \\
\hline Demografi* & - \\
\hline Topluluk Ağları** & 490 \\
\hline Roman Kimliğine İlişkin Öz-Algılar/Kanaatler & $\% 67,8$ \\
\hline Başkasına/Öteki'ne İlişkin Betimlemeler ve Anlatılar & 142 \\
\hline Roman Kimliği ve Ötekisini Illişkilendirme Biçimleri & 919,6 \\
\hline */**: Illk iki kategori, sahada/tartışma alanında paylaşılan tüm içeriklerde söz konusu olduğu için nicel olarak \\
ifade edilmemektedir. & $\% 12,6$ \\
\hline
\end{tabular}

Tablo 1'in çalışmanın kültürel analitiği açısından ifade ettiği durum, topluluk sayfasındaki kullanıcıların önemli oranda öz-kimliklerini referans alan bir üretim sinerjisine başvurarak restore ettikleri jeneriğin odağında olmayı seçtikleridir. Paylaşım içeriklerinde 'Öteki'yi ve onunla kurulan ilişkileri referans alan olumsuzluk gösterenleri ise yok sayılması mümkün olmayan bir oranla temsil edilmektedir. 'Biz' olarak ideal biçimde kurgulanan Roman kimliğinin görünürlüğü ve hükmettiği temsil alanı, Ötekinin işgal ettiği alandan çok daha fazla olması nedeniyle geleneksel medya alışkanlıklarının benzeri bir tablo ortaya çıkmaktadır.

Tablo 2: Sahadaki Paylaşımların Betimsel Kod Verileri

\begin{tabular}{|c|c|c|}
\hline Kategori & Betimsel Kod Tipi & Betimleyici Veri Setleri \\
\hline $\begin{array}{c}\text { Demografi } \\
\text { (67 Katılımcı Özelinde) }\end{array}$ & $\begin{array}{ll}\cdot & \text { Etnisite, } \\
\cdot & \text { Cinsiyet, } \\
\cdot & \text { Yaş, } \\
\text { - } & \text { Eğitim } \\
\end{array}$ & $\begin{array}{l}\text { Topluluk künyesi, yönetici ile } \\
\text { görüşmeler, katılımcıların açık } \\
\text { profilleri, otobiyografik yazılar, görsel } \\
\text { ve yazılı materyal paylaşımı, görüş } \\
\text { belirtimi, sayfa içi katılımlar. }\end{array}$ \\
\hline Topluluk Ağları & $\begin{array}{ll}\text { - } & \text { Kimlik Bağı, } \\
\text { - } & \text { Dayanışma/Yardımlaşma } \\
\text { - } & \text { Sempati/Antipati } \\
\text { - } & \text { Yerlilik/Yabancılık Bağı } \\
\text { - } & \text { Politik/Apolitik Bağ } \\
\text { - } & \text { Haberleşme/Duyurum } \\
\text { - } & \text { Demopedik Bağ } \\
\text { - } & \text { Arketipik Bağ } \\
\text { - } & \text { Arınma Bağı } \\
\text { - } & \text { Yönetici ile Bağlar } \\
\text { - } & \text { Üyeler Arası Bağlar }\end{array}$ & $\begin{array}{l}\text { Kolektif paylaşımlar, tartışmalar, } \\
\text { etkinlikler, tekil paylaşımlar, beğeniler, } \\
\text { Sahadaki görünür/izlenebilir } \\
\text { iletişimsel aksiyonlar, sınırlı görünür } \\
\text { iletişimsel aksiyonlar (yönetici ile } \\
\text { görüşme) }\end{array}$ \\
\hline
\end{tabular}




\begin{tabular}{|c|c|c|}
\hline $\begin{array}{l}\text { Roman Kimliğine İlişkin } \\
\text { Öz-Algılar/Kanaatler }\end{array}$ & $\begin{array}{ll}\text { - } & \text { Etnisite } \\
\text { - } & \text { Biz/Bizim/Bize Ait/Bizden Biri } \\
\text { - } & \text { Kimlik } \\
\text { - } & \text { Hak/Adalet/Eşitlik } \\
\text { - } & \text { Dil/Kültür/Sanat } \\
\text { - } & \text { Bilim/Eğitim } \\
\text { - } & \text { Gelişme/liyileşme } \\
\text { - } & \text { Birlik olma/Dayanışma } \\
\text { - } & \text { Olumsallık/Mutlak İyi }\end{array}$ & $\begin{array}{l}\text { Kolektif paylaşımlar, tartışmalar, } \\
\text { etkinlikler, tekil paylaşımlar, beğeniler, } \\
\text { Sahadaki görünür/izlenebilir } \\
\text { iletişimsel aksiyonlar, sınırlı görünür } \\
\text { iletişimsel aksiyonlar (yönetici ile } \\
\text { görüşme) }\end{array}$ \\
\hline $\begin{array}{l}\text { Başkasına/Öteki'ne İlişkin } \\
\text { Betimlemeler ve Anlatılar }\end{array}$ & $\begin{array}{ll}\cdot & \text { Etnisite } \\
\text { - } & \text { O/Onlar/Onlardan Biri/Öteki } \\
\text { - } & \text { Kötü/Düşman } \\
\text { - } & \text { Suçlu/Günah Keçisi } \\
\text { - } & \text { Dışarıdan/Yabancı } \\
\text { - } & \text { Roman Olmayan } \\
\text { - } & \text { Nefret Söylemi } \\
\end{array}$ & $\begin{array}{l}\text { Kolektif paylaşımlar, tartışmalar, } \\
\text { etkinlikler, tekil paylaşımlar, beğeniler, } \\
\text { Sahadaki görünür/izlenebilir } \\
\text { iletişimsel aksiyonlar, sınırlı görünür } \\
\text { iletişimsel aksiyonlar (yönetici ile } \\
\text { görüşme) }\end{array}$ \\
\hline $\begin{array}{l}\text { Roman Kimliği ve Ötekisini } \\
\text { İlişkilendirme Biçimleri }\end{array}$ & $\begin{array}{ll}\text { - } & \text { Uzak Durma } \\
\text { - } & \text { Dışlama/Ayrım } \\
\text { - } & \text { Anlaşma/Müzakere/Uzlaşma Kısas } \\
\text { - } & \text { Biz ve Onlar } \\
\text { - } & \text { İyi Biz/Kötü Öteki } \\
\text { - } & \text { Bizden mi, Değil mi? }\end{array}$ & $\begin{array}{l}\text { Kolektif paylaşımlar, tartışmalar, } \\
\text { etkinlikler, tekil paylaşımlar, beğeniler, } \\
\text { Sahadaki görünür/izlenebilir } \\
\text { iletişimsel aksiyonlar, sınırlı görünür } \\
\text { iletişimsel aksiyonlar (yönetici ile } \\
\text { görüşme) }\end{array}$ \\
\hline
\end{tabular}

Yukarıda tanımlanan betimsel kod tipleri ve onları içeren, kuran ve dönüştüren veri setleri arasındaki kültürel bağ, Roman kimliğinin sosyo-dijital restorasyonundaki yönelimin baskınlık düzeylerini elde etmeye yardımcı olmaktadır. Mevcut tablo özelinde açımlanan kimlik ilişkileri, kültürel üretimin özündeki kodifiye yaklaşımını vermesi bakımından da önemlidir.

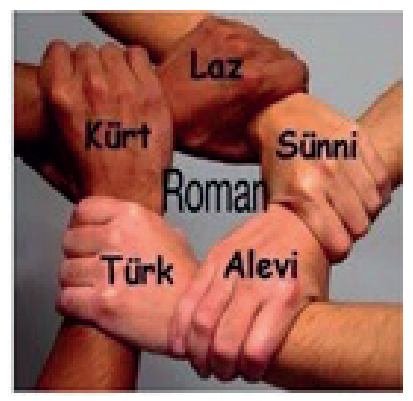

Görsel 1: 'Türk' Olmanın 'Roman' Hali

Türk, Laz, Kürt, Alevi, Sünni, Roman kimliklerinin bir arada Türkiye'yi oluşturduğu vurgusu yapan bu paylaşım Romanların Türkiye'nin asli unsurlarından olduğunu da pekiştirmektedir. Ancak bu görsel hakkında küçük bir detay paylaşmak gerekirse, dolaşımdaki aslında Roman ifadesinin yer almadığı belirtilmelidir. Roman kullanıcılar kendilerini bu görseldeki mesajın bir yerine eklemeyi amaçladıklarında, merkezde yer almayı seçmiştir. 